\title{
SIMULATION OF UNSTEADY FLOW IN THE
} MILWAUKEE HARBOR ESTUARY AT MILWAUKEE, WISCONSIN
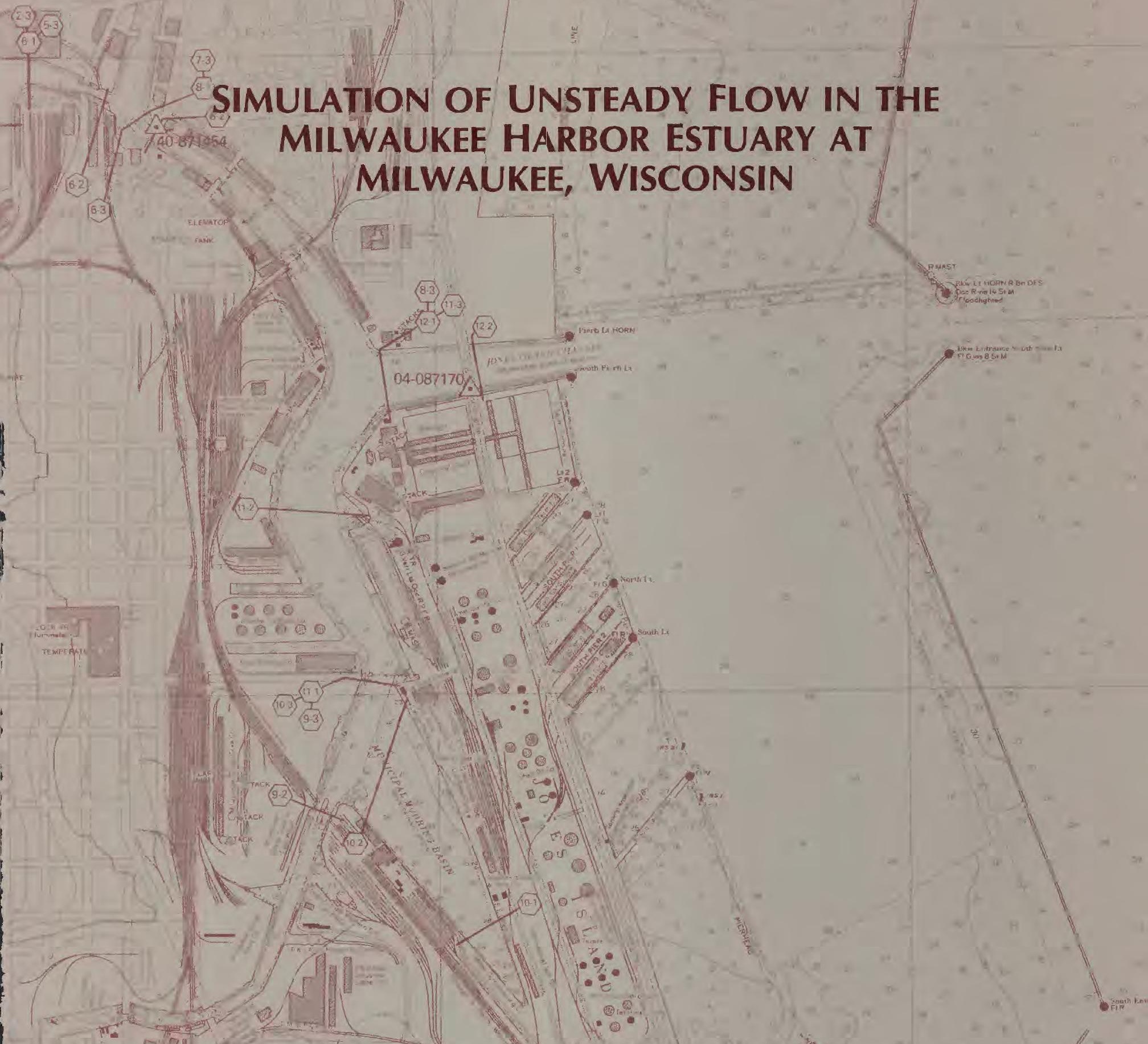

Prepared by

UNITED STATES DEPARTMENT OF THE INTERIOR

\section{GEOLOGICAL SURVEY}

In cooperation with the SOUTHEASTERN WISCONSIN REGIONAL PLANNING COMMISSION

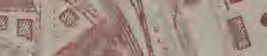




\title{
SIMULATION OF UNSTEADY FLOW IN THE MILWAUKEE HARBOR ESTUARY AT MILWAUKEE, WISCONSIN
}

\author{
By Leo B. House
}

Water-Resources Investigations Report 86-4050

Prepared by

UNITED STATES DEPARTMENT OF THE INTERIOR

GEOLOGICAL SURVEY

In cooperation with the

SOUTHEASTERN WISCONSIN REGIONAL PLANNING COMMISSION

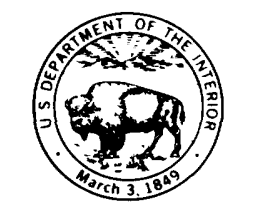

Madison, Wisconsin

March, 1987 


\section{UNITED STATES DEPARTMENT OF THE INTERIOR \\ DONALD PAUL HODEL, Secretary}

GEOLOGICAL SURVEY

Dallas L. Peck, Director

For additional information write to:

District Chief

U.S. Geological Survey

6417 Normandy Lane

Madison, Wisconsin 53719
Copies of this repirt can be purchased from:

Open-File Servicer Section Western Distribution Branch U.S. Geological Sirvey Box 25425, Feders' Center Lakewood, Colora do 80225 (Telephone: (303) 234-5888) 


\section{CONTENTS}

Abstract $\ldots \ldots$

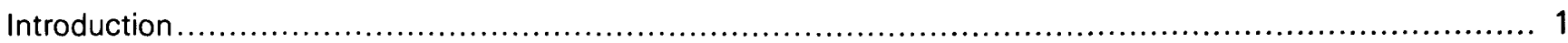

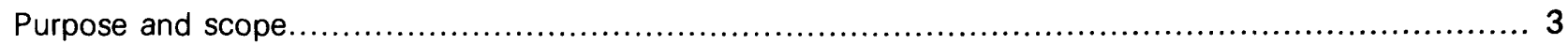

Milwaukee Harbor Estuary unsteady-flow model........................................................ 3

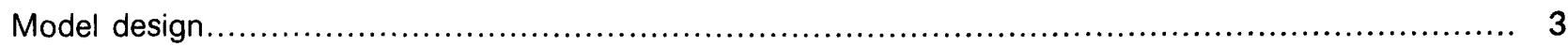

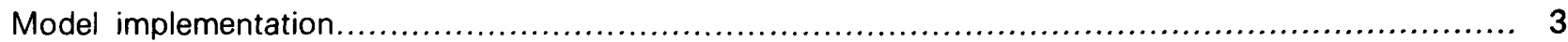

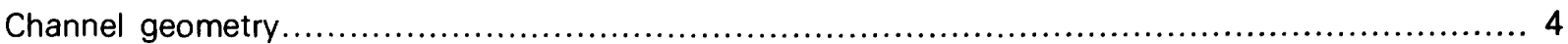

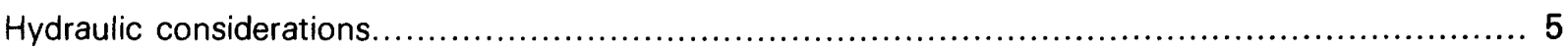

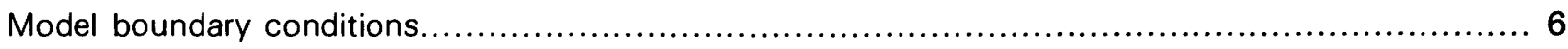

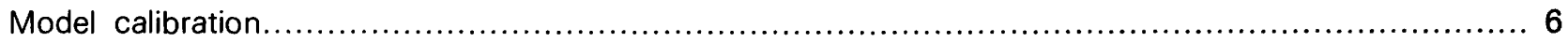

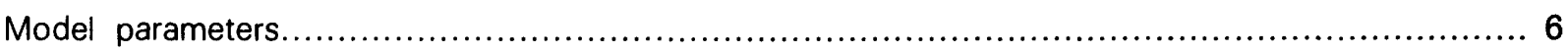

Comparison of discharge computations using various computation intervals........................ 9

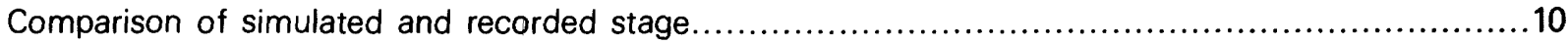

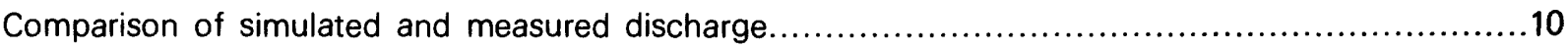

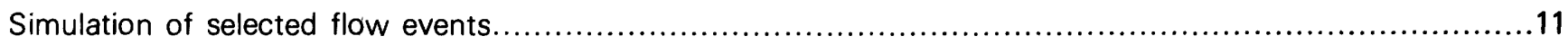

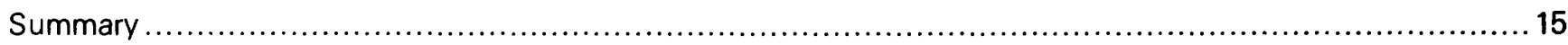

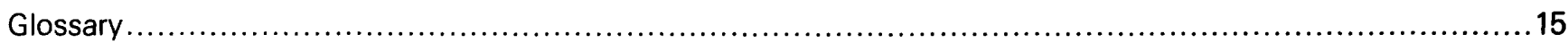

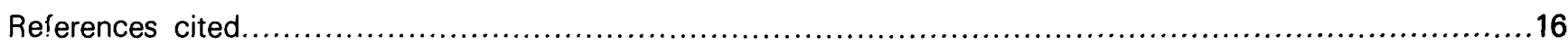

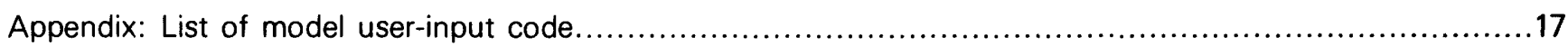

\section{ILLUSTRATIONS}

Plate 1. Map of Milwaukee Harbor Estuary showing location of cross sections (in pocket)

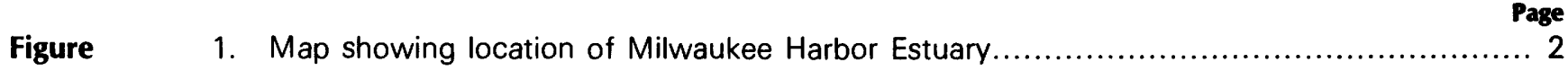

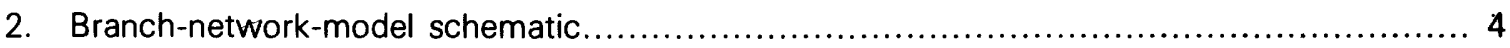

3. Graph showing Jones Island and Coast Guard base stage plots,
September $8,1983 \ldots \ldots \ldots \ldots \ldots \ldots \ldots \ldots \ldots \ldots \ldots \ldots \ldots \ldots \ldots \ldots \ldots \ldots \ldots \ldots \ldots \ldots \ldots \ldots \ldots \ldots \ldots \ldots \ldots \ldots \ldots \ldots \ldots \ldots \ldots \ldots \ldots \ldots \ldots$

4. Graph showing comparison of simulated and recorded stage at Water Street,

September 8, 1983........................................................................11

5. Graph showing simulated discharge for Milwaukee River at Jones Island,

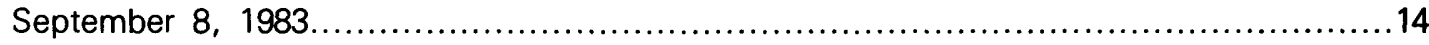

\section{TABLES}

Table

1. Summary of model boundary conditions and key cross-section locations.

2. Comparison of daily average discharge computations,

March 28-April 9, 1983.

3. Comparison of maximum and minimum model discharge computations,

Milwaukee River at mouth, (Jones Island channel)

March 28-April 9, 1983. 
4. Simulation of Milwaukee Harbor Estuary discharge, November 7-12, 1983.................12

5. Simulation of Milwaukee Harbor Estuary discharge, March 28-April 9, 1983.................12

6. Simulation of Milwaukee Harbor Estuary discharge, August 9-14, 1983....................12

7. Simulation of Milwaukee Harbor Estuary discharge, September 10-14, 1983................12

8. Simulation of Milwaukee Harbor Estuary discharge, October 10-20, 1983..................13

9. Simulation of Milwaukee Harbor Estuary discharge, February 10-21, 1984..................13

10. Simulation of Milwaukee Harbor Estuary discharge, September 20October 10, 1983............................................................................ 13

\section{FACTORS FOR CONVERTING INCH-POUND TO METRIC (SI) UNITS}

For readers who prefer to use metric (International System) units rather than the inch-pound units used in this report, conversion factors are listed below.

Multiply inch-pound unit

foot $(\mathrm{ft})$

mile (mi)

acre

square mile $\left(\mathrm{mi}^{2}\right)$

cubic foot per second $\left(\mathrm{ft}^{3} / \mathrm{s}\right)$
By

0.3048

1.609

4,047

2.590

0.02832
To obtain SI unit

meter (m)

kilometer $(\mathrm{km})$

square meter $\left(\mathrm{m}^{2}\right)$

square kilometer $\left(\mathrm{km}^{2}\right)$

cubic meters per second $\left(\mathrm{m}^{3} / \mathrm{s}\right)$ 


\title{
SIMULATION OF UNSTEADY FLOW IN THE MILWAUKEE HARBOR ESTUARY AT MILWAUKEE, WISCONSIN
}

\author{
By Leo B. House
}

\section{ABSTRACT}

This report describes the application and results of an unsteady-flow model for the Milwaukee Harbor Estuary. The model simulates unsteady and upstream flow occurring in the estuary as a result of Lake Michigan seiche. The discharge computed by the model indicates that upstream flow occurs throughout the estuary during periods of lake seiche. Flow conditions are extremely unsteady and major flow reversals may occur within 1 hour. The simulated discharge indicates that both upstream and downstream flows four times greater than the average daily discharge can occur during the same day.

An estimate of 5- or 15-minute average discharge was required during selected runoff events and at various locations in the estuary as part of the Milwaukee Harbor Estuary study, which was conducted in cooperation with the Southeastern Wisconsin Regional Planning Commission. The model provides a method to estimate 5-minute average discharges at selected cross sections in the estuary.

The U.S. Geological Survey's Branch Network Model was used to simulate stage and discharge. A finitedifference computation scheme is used to solve the onedimensional flow equations. Model-input requirements include channel-geometry data, discharge at the upstream tributaries, and stage data at the estuary mouth.

The model was used to simulate flow during six selected time periods in 1982-84 using a 5- or 15-minute computation interval.

\section{INTRODUCTION}

The Milwaukee Harbor Estuary is located or the eastern edge of the city of Milwaukee adjacent to Lake Michigan (fig. 1). The estuary is formed by the convergence of the Milwaukee, Menomonee, and Kinnickinnic Rivers with Lake Michigan. The estuary consists of the three tributaries, an inner harbor, and an outer harbor area (fig. 1). The riverine area of the estuary extends $3 \mathrm{mi}$ upstream from the mouth of the Milwaukee River to the dam near North Avenue, $2.2 \mathrm{mi}$ upstream from the Menomonee River's confluence with the Milwa ukee River up to a low-head dam near 35th Street, an 1.7 mi upstream from the mouth of the Kinnickinnic River to South Chase Avenue (see detail on pl. 1). The Milwaukee and Menomonee Rivers flow into the inner harbor area from the northwest. The Kinnickinnic River flows from the southwest into the inner harbor area known as the "turning" or "mooring" basin. The inner harbor area is connected to the much larger oute- harbor area by a 2,000 ft long channel (Jones Island channel). The estuary is navigable by Great Lakes vessels except for the upper reaches of the Milwaukee and Kinnickinnic Rivers where dredging has been discontinued.

The estuary tributaries have a combined watershed drainage area of $856 \mathrm{mi}^{2}$. The Milwaukee, Menomonee, and Kinnickinnic Rivers have watershed areas of 702.134, and $20.2 \mathrm{mi}^{2}$, respectively (U.S. Geological Survey, 1984).

Discharge through the inner-to-outer harbor connecting channel is a function of both the tributary' river inflow to the inner harbor and the Lake Michigan seiche. 

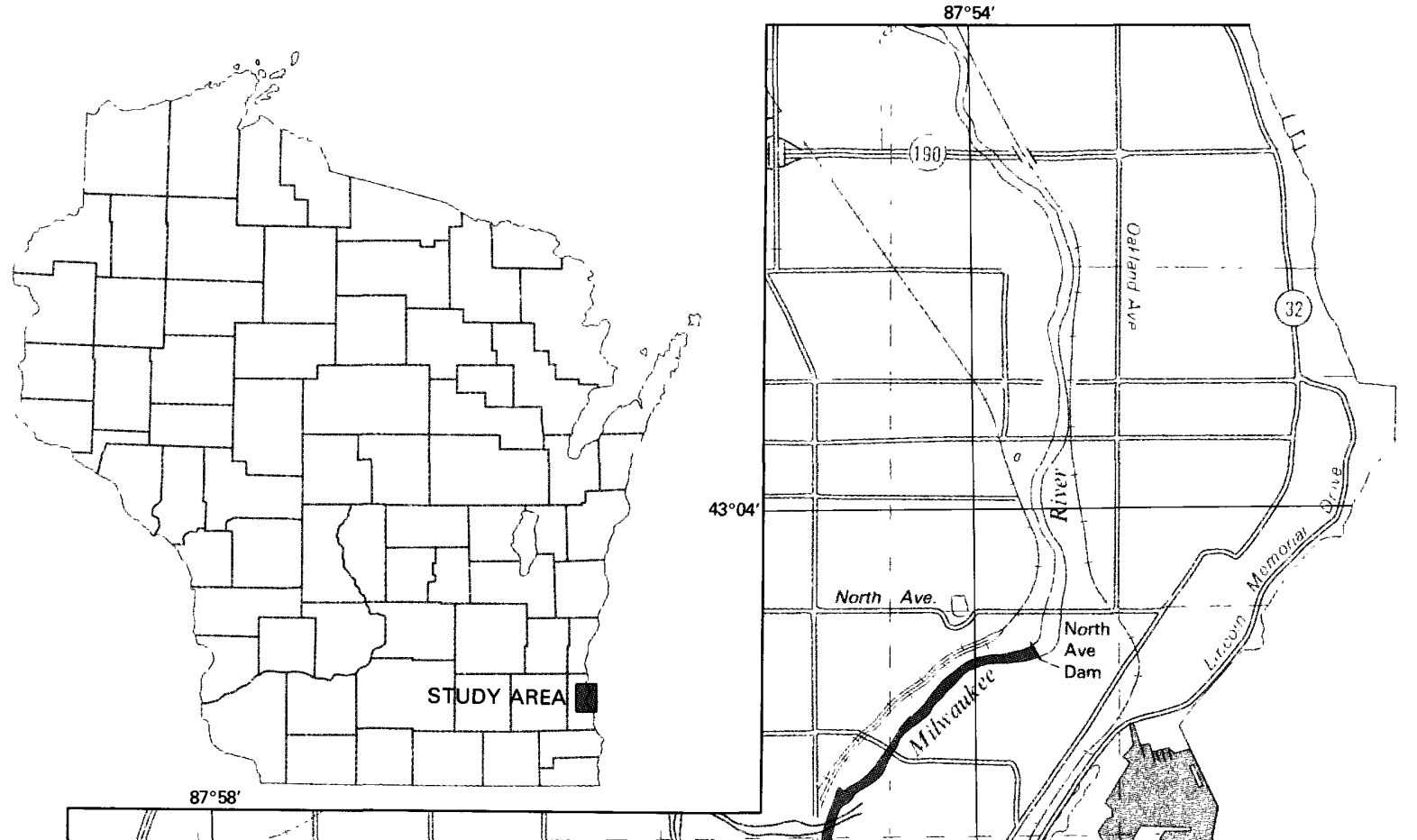

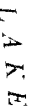

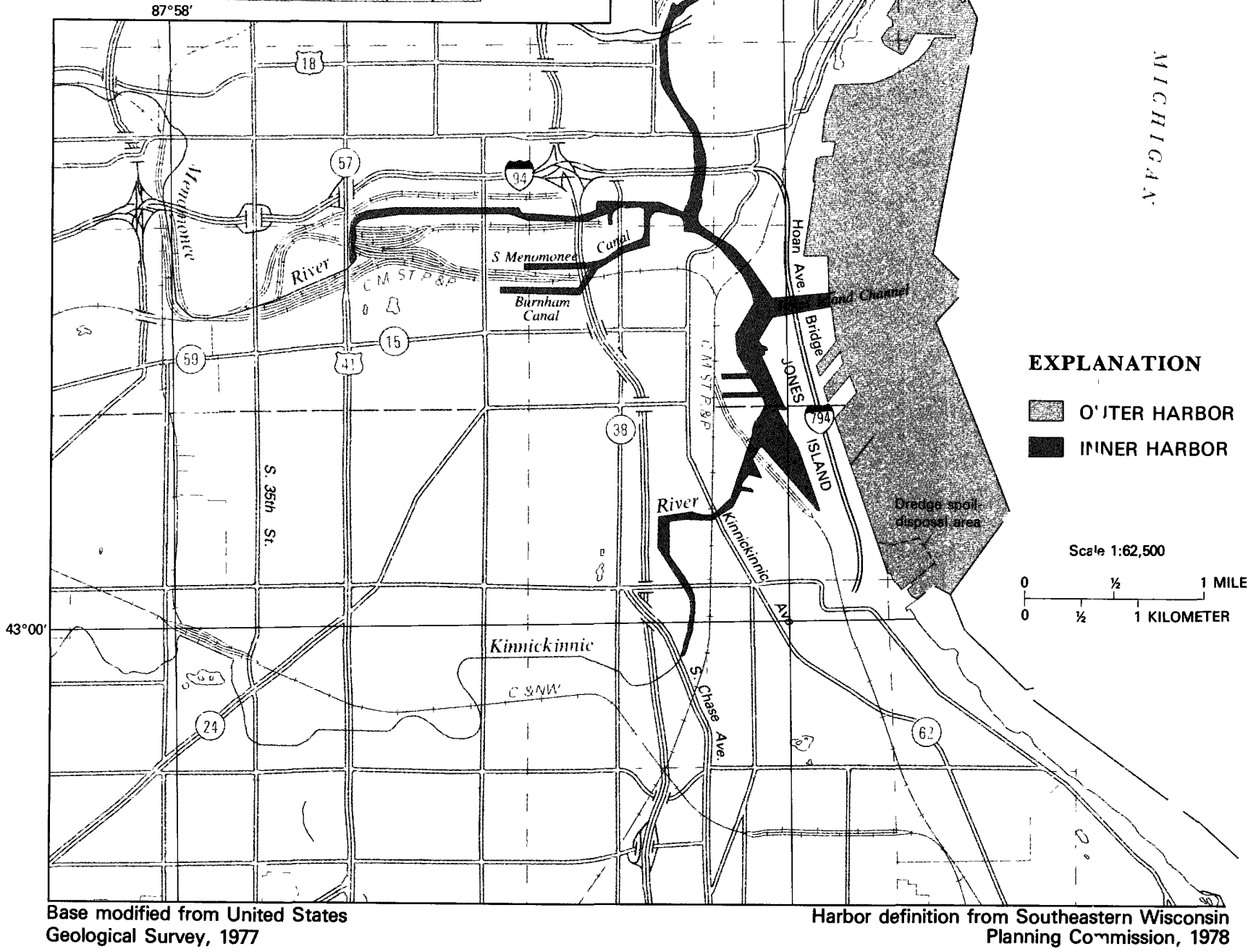

Figure 1. Location of Milwaukee Harbor Estuary. 
Flow conditions in the channel are extremely unsteady; alternating upstream and downstream discharges may occur within an hour. Existing gaging stations are only capable of providing average daily discharge data within the estuary. Therefore, discharges within the harbor were estimated by use of a flow model.

The purpose of this project is to estimate discharge at selected locations within the estuary. This effort is part of the comprehensive Milwaukee Harbor Estuary study (MHES) conducted cooperatively by the U.S. Geological Survey, the Southeastern Wisconsin Regional Planning Commission (SEWRPC), and the Milwaukee Metropolitan Sewerage District (MMSD). Other U.S. Geological Survey project elements included water-quality sampling efforts, operation of seven stream-gaging stations with automated suspended sediment samplers, and a groundwater-quality investigation of the Menomonee River valley within the estuary (Southeastern Wisconsin Regional Planning Commision, 1981).

\section{Purpose and Scope}

The purpose of this report is to describe the simulation of flow in the Milwaukee Harbor Estuary by use of a one-dimensional unsteady-flow model. The model simulates discharge for the Lake Michigan backwateraffected tributary reaches, the inner harbor, and the inner-to-outer harbor connecting channel. The modeled area encompasses 1,630 acres of surface water and includes $6.9 \mathrm{mi}$ of river length (Southeastern Wisconsin Regional Planning Commission, 1981). In addition to the three major tributary reaches, the estuary contains two shipping canals with significant storage. These canals are known as the Burnham and South Menomonee Canals; they are located adjacent to the Menomonee River upstream of its confluence with the Milwaukee River (pl. 1).

The model was used to simulate discharge at 5- or 15-minute intervals, including stage, average crosssectional velocity, and net discharge for selected cross sections in the Jones Island channel, in the inner harbor, and in the backwater-affected estuary tributaries. Discharge in the outer harbor area was not simulated by the model. Continuous discharge was simulated for selected time periods that correspond to the waterquality-sampling efforts referred to previously. Six such periods were simulated during the 1982-84 water years.' Simulation periods ranged from 5 to 13 days for various flow conditions.

\section{MILWAUKEE HARBOR ESTUARY UNSTEADY-FLOW MODEL}

A branch-network unsteady-flow model (Schaffranek and others, 1981) was used to simulate the stage and discharge throughout the estuary. This one- dimensional (horizontal direction) model is based $\mathrm{c} n$ an implicit, finite-difference formulation of the continuity' and momentum flow equations. The model's discharge and velocity outputs represent the cross-sectional avera.1e at a given channel location. The model can accommc fate local point-source inflow and diversion and also "creadend" channel-boundary conditions.

\section{Model Design}

The model schematic of the estuary is depict?d in figure 2. The schematic consists of 12 branches or subreaches bounded by external or internal junction node points. Each branch is represented in the model by at least two channel cross sections to reflect local hydraulic characteristics. Actual cross-section locations are st own on plate 1. The same cross section is used to reprisent both the downstream end of one branch anc the upstream end of another at an internal junction.

External junction numbers 5, 8, and 10 are us $: d$ to represent the upstream boundaries of the Milwaukee, Kinnickinnic, and Menomonee Rivers, respectively. The computational boundary conditions at these junctiore are given to the model as continuous discharge records. These discharge records are obtained from nearby gaging stations.

External junction numbers 7,12 , and 13 are us?d to represent the upstream endpoints of the Muninipal Mooring Basin, the South Menomonee Canal, ant the Burnham Canal, respectively. The boundary cond tions at these junctions are given to the model as zerodischarge (null) flow equations.

External junction number 1 represents the downstream end of the Jones Island channel that connects the inner and outer harbor areas. Continuous stage records are given to the model as the endpoint boundary condition. The stage records used were obtained from U.S. Geological Survey stage recorders at the Jones Island site and/or from the U.S. Coast Guard station during periods when the Jones Island recorder malfunctioned.

The Wisconsin Electric Power Company (WCPCO) powerplant diverts cooling water from the Menomonee River. This is represented by a withdrawal of $250 \mathrm{ft}^{3} / \mathrm{s}$ at junction number 9 and a $250 \mathrm{ft}^{3} / \mathrm{s}$ inflow at jurstion number 11.

\section{Model Implementation}

Channel conveyance and storage characteristins for each model segment of the estuary were defined by cross-sectional geometry, segment length, Manning's roughness coefficient, and the velocity-distrik'stion momentum coefficient. Of these, channel geometry and segment length were measured values. Manning's roughness coefficient and the momentum coefficient

\footnotetext{
' A water year runs from October 1 through September 30 of the following year.
} 
were initially estimated and then adjusted during the model-calibration procedure to obtain the best agreement between simulated and recorded data. A discussion of various harbor characteristics affecting the model's implementation is given in the following sections.

\section{Channel Geometry}

The inner harbor is dredged to maintain a $27-\mathrm{ft}$ navigation depth. The Menomonee and lower Kinnickin- nic Rivers are dredged to maintain a $21-\mathrm{ft}$ navigation depth. Channel geometry tends to be very uniform because of maintenance dredging. The cross-section locations used to define the model segments were selected to represent the average hydraulic conditions in a segment or to represent a significant constriction within a branch. Care was also taken in locatinc cross sections so that the total channel storage capacity was accounted for in the model.

\section{EXPLANATION}

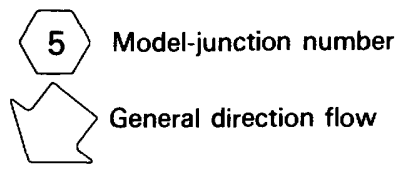

DIAGRAM NOT TO SCALE

North Ave. Dam<smiles>C1CCCC1</smiles>

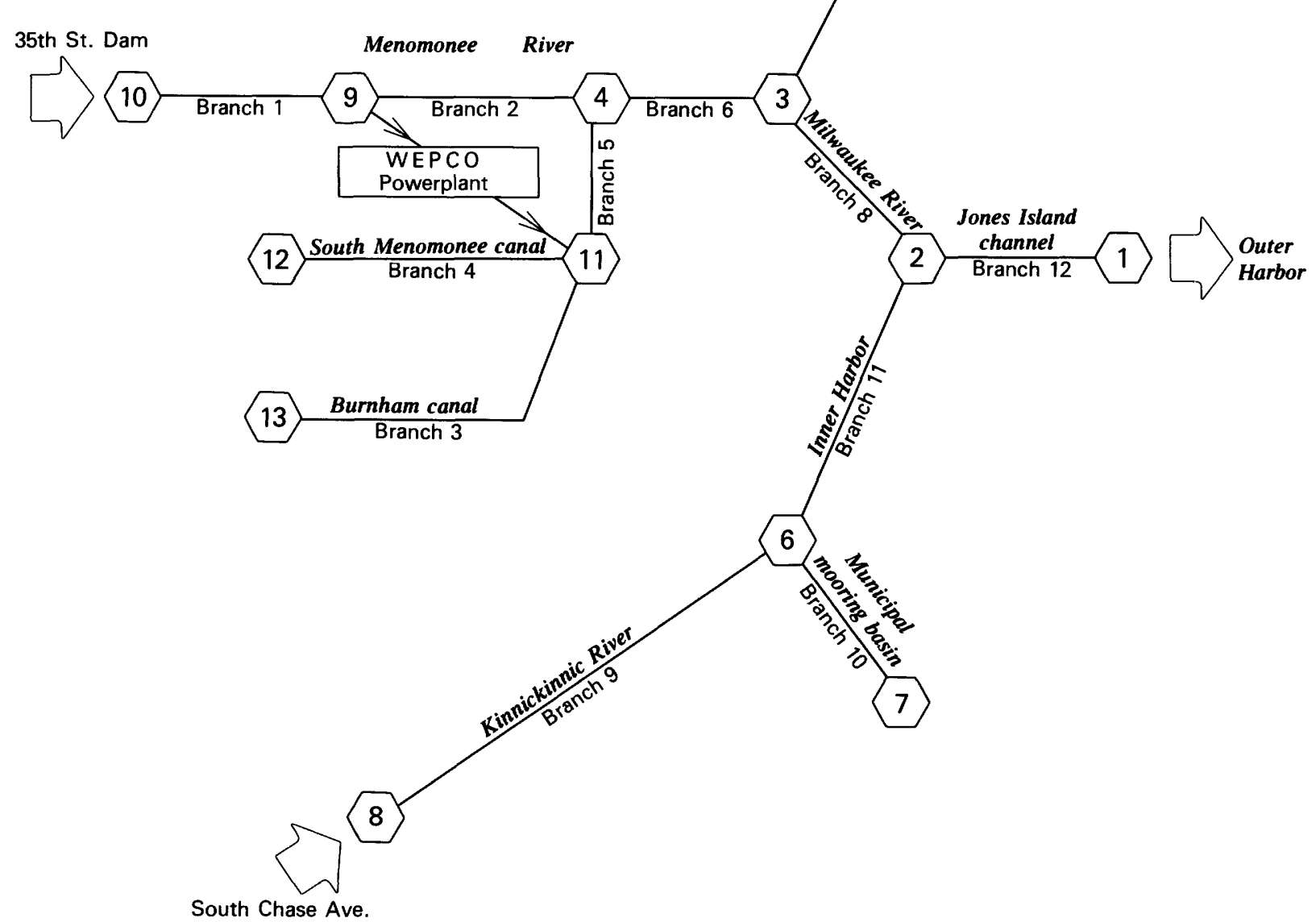

Figure 2. Branch-network-model schematic. 
Cross-sectional-geometry data were obtained from the U.S. Army Corps of Engineers' (Corps) bathymetric maps of the estuary. These maps are made in conjunction with the Corps' navigational dredging operations. Data for the Menomonee River, Kinnickinnic River, and the inner harbor area were obtained from maps made after the December 1981 dredging operation. The Milwaukee River has not been maintained for navigational purposes upstream of East Buffalo Street since 1955. Channel-geometry data for the Milwaukee River upstream of East Buffalo Street were obtained from soundings made by the Corps in May 1983. Channel segment lengths were determined using Corps 1 inch $=100$ feet bathymetric maps and U.S. Geological Survey 1:24,000 quadrangle maps.

\section{Hydraulic Considerations}

A number of factors that affect estuary hydraulics, in addition to tributary inflow and outer harbor stage, were considered in model application. These factors included the WEPCO powerplant cooling water diversion, operation of two low-flow augmentation flushing tunnels in the estuary, and local watershed inflow to the estuary downstream of the gaging stations. These factors are discussed in the following paragraphs.

The WEPCO powerplant is located between the Menomonee River and the South Menomonee Canal. The powerplant diverts $250 \mathrm{ft}^{3} / \mathrm{s}$ from the Menomonee River near South 11th Street (pl. 1) and discharges heated water into the South Menomonee Canal. This diversion exceeds the average flow of the Menomonee River of 92 $\mathrm{ft}^{3} / \mathrm{s}$ (U.S. Geological Survey, 1984). During summer, the river flow typically drops below $20 \mathrm{ft}^{3} / \mathrm{s}$. Previous physical model studies performed by the Massachussets Institute of Technology (Harleman and Stolzenbach, 1967) indicated that cooling water required in excess of the Menomonee River flow was obtained via an upstream flow of Lake Michigan or Milwaukee River water along the channel bottom. The cooling water discharged to the South Menomonee Canal is warmer than the upstreamflowing water and remains at the surface as it flows downstream. Therefore, two distinct flow layers with opposing flow directions may be present in the Menomonee River and the inner harbor area. The physical-model results are supported by temperature measurements made in the Menomonee River at the Muskego Avenue and S. Second Street bridges and in the Milwaukee River at Water Street. These measurements were made as part of this study during related water-quality-sampling events. The temperature measurements indicate colder Lake Michigan water is periodically present along the channel bottom at all three sites.

The branch-network model used in this study simulates only the net average discharge and velocity at a cross section. The model does not compute flo'v in multiple layers. During periods of low flow in the Menomonee River the model computation results apear to indicate that a recirculation of cooling water is occurring along a path from junction 9, through the WEPCO powerplant, to junction 11 , to junction 4 , and back to junction 9 (fig. 2). During periods of Menomonee River flow in excess of $250 \mathrm{ft}^{3} / \mathrm{s}$, no such recirculation is indicated. There is not actually any recirculation of hot water because the cooling water is withdrawn from the upstream flow along the bottom while the warmer discharge water is flowing downstream on the surface. The net average discharge and velocity results comp' ited by the model for branches number $2,6,8$, and 12 are correct but do not indicate the two-layer flow regime. The net average flow velocity computed by the rrodel at a cross section is different from what would act rally be measured in either the surface or bottom flow la'rers.

One way to avoid the apparent recirculation resilts is to omit branches number 3,4 , and 5 from the model configuration and combine branches number 1,2 , and 6 into a single branch. This results in a computationally more efficent model but sacrifices representation of the channel storage in the South Menomonee and Burrham Canals. Accordingly, the more complex model configuration was used.

The Milwaukee Metropolitan Sewerage Di-trict (MMSD) operates two low-flow augmentation "fluching tunnels" that divert water from the outer harbor area and discharge into the Kinnickinnic and Milwaukee Rivers (pl. 1). The Kinnickinnic River flushing tunnel diverts water from near the U.S. Coast Guard base and discharges to the river at South Chase Avenue. The Milwaukee River flushing tunnel diverts water from near the McKinley Marina and discharges into the rive- just downstream of the North Avenue Dam. The Kinnickinnic and Milwaukee River flushing tunnels have rated discharge capacities of 410 and $334 \mathrm{ft}^{3} / \mathrm{s}$, respectively (Milwaukee Metropolitan Sewerage District, written commun., 1984). This discharge compares to an average discharge of 27 and $647 \mathrm{ft}^{3} / \mathrm{s}$ for the Kinnickinnic and Milwaukee Rivers, respectively, during the 1983 water year (U.S. Geological Survey, 1984). Obviously, flushingtunnel operation has a significant impact or the hydraulics within the estuary. However, the tunnels were not in operation during the selected event periods simulated by the model and, therefore, were not represented. If the model is used to simulate periods with flushing-tunnel operation, the inflow would need to be accounted for by adding it to the upstream dischargeboundary conditions at external junction numbers 8 and 5 (fig. 2).

The stormwater runoff from the ungaged estuary watershed area downstream of the gaging station: was not considered to be significant for hydraulic- 
computation purposes. This $24.9-\mathrm{mi}^{2}$ area composes less than 3 percent of the watershed area upstream of the estuary that contributes tributary inflow. Most of this area is serviced by combined sanitary and storm-sewer collectors, and the near-shore areas are very pervious. Therefore, inflow from this ungaged area was not included in the model.

\section{Model Boundary Conditions}

Stage and discharge boundary condition data provide the "driving force" to run the model. Previous applications of the U.S. Geological Survey branch-network model typically used continuous stage records as the external model boundary conditions (Holtschlag, 1981; Stedfast, 1982). The Milwaukee Harbor Estuary branchnetwork model employs continous discharge data as the upstream tributary boundary conditions. This was done to accommodate the free-fall dam at North Avenue on the Milwaukee River and a submerged dam near 35th Street on the Menomonee River. If a stage boundary condition is used, the model's computational scheme assumes an unbroken water-surface profile and does not account properly for the Lake Michigan seiche-wave reflection from the North Avenue dam that has been observed. Correct computational results would not be obtained using boundary-condition data obtained from a stage recorder downstream from the dam because of this wave reflection. Therefore, a discharge-boundary condition was required for the Milwaukee River at North Avenue Dam.

The model cannot be used to simulate stage and discharge when abrupt changes in channel geometry occur within a short distance. Such a situation occurs in the vicinity of a submerged dam on the Menomonee River near 35th Street (pl. 1), at the upstream end of the estuary. A discharge-boundary condition was used just downstream of the dam and the abruptly changing channel geometry was omitted. Using a stage-boundary condition in the vicinity of the dam would have the same seiche-reflection problems as at the North Avenue Dam site. A discharge-boundary condition was also used at the upstream end of the Kinnickinnic River estuary at South 7th Street, where a gaging station was in operation at the start of the study.

The Menomonee and Kinnickinnic River gaging stations were affected by rising Lake Michigan levels during the second year of the study. The Kinnickinnic River gaging station was relocated to South 11th Street for this reason. The Menomonee River gage upstream at 70th Street was used to estimate discharge at the 35th Street site during periods of backwater effect (pl. 1).

Continuous 5-minute stage records were used as the boundary condition at the Jones Island channel entrance. Problems with recorder malfunctions eventually led to the installation of two additional recorders at the site to provide backup data-collection capabilities. Stage records from the U.S. Coast Guard station at the southern end of the outer harbor were used to replace rnissing records during periods when the Jones Island recorder failed.

Comparative plots of the Jones Island and U.S. Coast Guard base stage recorders for a daily period when both recorders were functioning properly' are shown in figure 3. The magnitude of the stage-record oscillations compares well between the two sites as c'oes the timing of the maximum and minimum stage values. The recorded stages at the two stations were within $0.1 \mathrm{ft}$ of each other and peak timing is within 15 minutes. The overall plot comparison indicates that no significant errors would occur using the U.S. Coast Guard base stage records to substitute for the Jones Island missing records.

Zero-discharge (null) external boundary conditions were used for the dead-end South Menomonee and Burnham Canals and for the Municipal -urning Basin. The channels were included in the mode' schematic to assure that the total estuary channel storage was represented. Simulating the discharge witr' $n$ these channels was not a primary concern. Table 1 summarizes the external-boundary condition type used for each external junction node referenced to the model scrematic shown in figure 2.

\section{Model Calibration}

The model was calibrated by adjusting model parameters until simulated results were in good agreement with observed values. Simulatef stage was generally within $0.1 \mathrm{ft}$ of that observed (recorded). The model parameters adjusted, or considered for adjustment, were the water-surface wind-drag coefficient, velocitydistribution momentum coefficient, Manning's channel roughness factor, finite-difference weighting factor, and the geometry weighting factor. Model sensitivity to 5-, 15-, or 60-minute computational intervals also was tested. The model's simulated average daily outflows at the Jones Island channel were compared to the total average daily tributary inflow to the estuary, and the simulated stage within the estuary was compared to recorded stage within the estuary. Unfortunately, it proved impossible to make actual discharge measurements at the Milwaukee River mouth (Jones Island channel), so a comparison of simulated and measured discharge could not be made.

\section{Model Parameters}

The branch-network model used in this study can account for wind-drag flow resistance. Ir order to use this capability, the user inputs channel orientation data for each model branch and also provides time-variable wind speed and direction data. An adjustable watersurface drag coefficient also is provided. Early versions 
of the Milwaukee Harbor Estuary model incorporated the wind-effects simulation. However, there was no significant difference in results when using a model without the wind simulation. Therefore, the final model sim' ilations did not include wind effects. The probable reason that there was no significant difference in model reasults

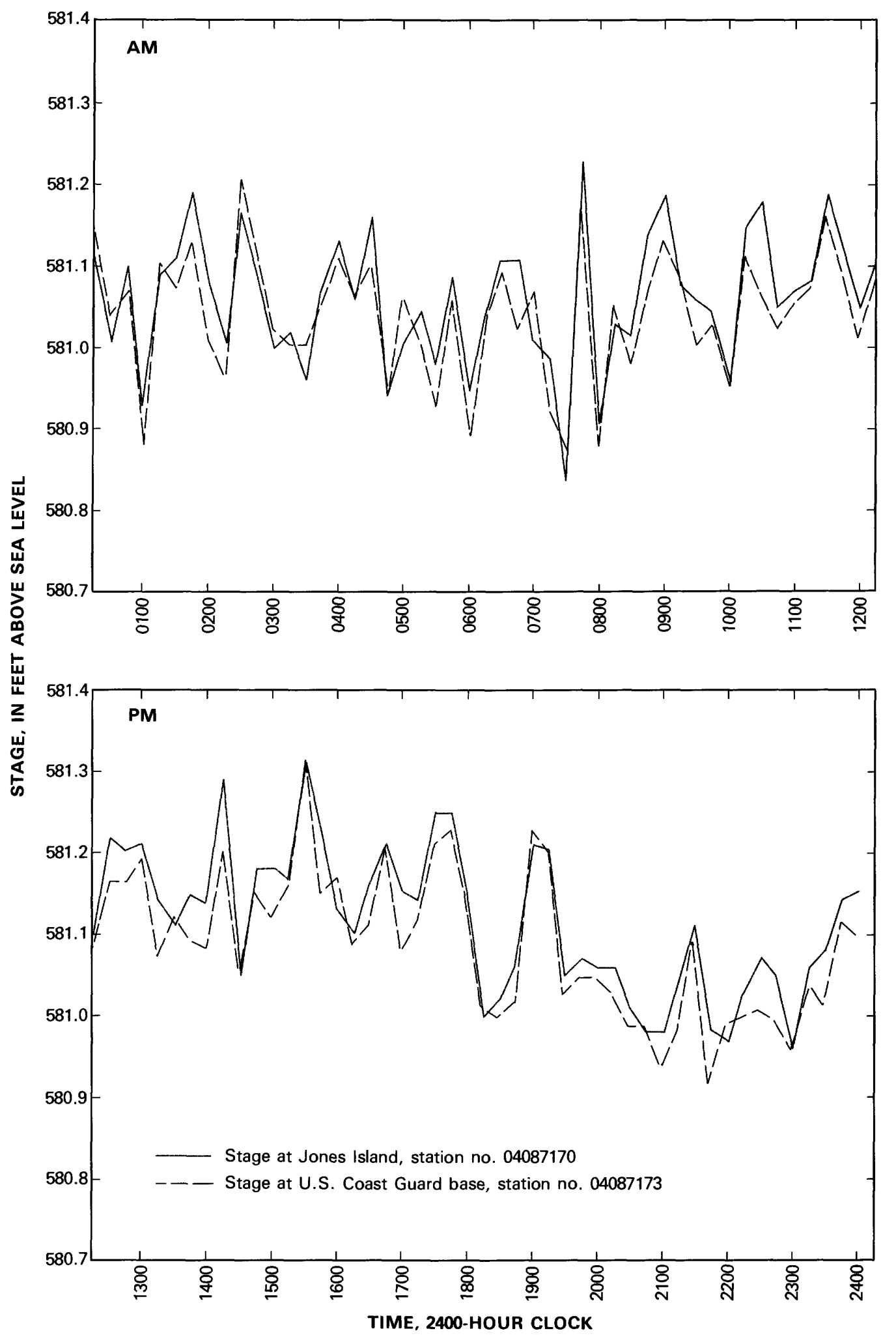

Figure 3. Jones Island and Coast Guard base stage plots, September 8, 1983. 
is because of the short branch lengths involved. Much of the estuary is sheltered from wind effects by tall buildings, which further reduces the effects of wind.

The velocity-distribution-related momentum coefficient is used to account for a nonuniform velocity distribution over a channel cross section. Flow momentum always is greater than that computed, assuming a uniform average velocity, so a correction factor is applied to the momentum flow equation. This correction factor (momentum coefficient) can be computed using crosssectional and vertical-profile velocity measurements. Unfortunately, the flow conditions in the estuary are too unsteady to complete such a measurement before a significant change in flow occurs. Therefore, it was not possible to compute momentum coefficients for use in the model.

Values of the momentum coefficient used in previous model applications (Holtschlag, 1981; Stedfast, 1982) range from 1.00 to 1.06 ; values of 1.00 to 1.02 were typical. Chow (1959) also found typical values in this range. Therefore, a value of 1.00 was used for the inner harbor branches and the Jones Island channel and a value of 1.02 for the upstream tributary brancher. These values appeared to give good simulation results.

The value of the Manning channel roughness factor had virtually no effect on the model's velocity and discharge results. An initial estimate of $0.0 ? 4$ was doubled to 0.048 and halved to a value of 0.012 without any apparent change in results. The lack of model sensitivity to the roughness factor is probably relat?d to the large dredged cross-sectional areas of the channels relative to the discharge and the relatively short reach lengths. Therefore, an average roughness coefficient of 0.024 was used throughout the estuary.

The parameters that did have a significant effect on the model's computed results were the f'nite-difference weighting factors, theta and chi. These parameters affect the finite-difference computation scheme used in the model. The finite-difference weighting factor, theta, determines the time within the computaticn interval when the spatial derivatives of the stage and discharge are evaluated. The weighting factor, chi, similarly determines

Table 1. Summary of model boundary conditions and key cross-section locatic ns

\begin{tabular}{|c|c|c|c|}
\hline $\begin{array}{c}\text { External } \\
\text { boundary } \\
\text { junction } \\
\text { number } \\
\text { (fig.2) }\end{array}$ & $\begin{array}{c}\text { Type } \\
\text { of } \\
\text { boundary } \\
\text { data }\end{array}$ & $\begin{array}{l}\text { U.S. Geological } \\
\text { Survey station } \\
\text { number }\end{array}$ & Comments \\
\hline 1 & Stage & 04087170 & $\begin{array}{l}\text { Stage recorder at Jones Island channel (Milwaukee River at } \\
\text { mouth) }\end{array}$ \\
\hline 1 & Stage & 04087173 & $\begin{array}{l}\text { Stage recorder at Coast Guard station, used for backup pur- } \\
\text { poses }\end{array}$ \\
\hline 5 & Discharge & 04087010 & Gaging station at North Avenue Dam \\
\hline 7 & Null & N/A & Zero-discharge boundary \\
\hline 8 & Discharge & 04087160 & $\begin{array}{l}\text { Gaging station at South 7th Street (discontir'sed } \\
\text { January 1983) }\end{array}$ \\
\hline 8 & Discharge & 04087159 & $\begin{array}{l}\text { Gaging station at South } 11 \text { th Street, used after } 04087160 \\
\text { discontinued }\end{array}$ \\
\hline 10 & Discharge & 04087138 & Gaging station at South 35th Street \\
\hline 12 & Null & N/A & Zero-discharge boundary \\
\hline 13 & Null & N/A & Zero-discharge boundary \\
\hline \multicolumn{2}{|c|}{$\begin{array}{l}\text { Cross section ID } \\
\quad \text { (plate 1) }\end{array}$} & \multirow{2}{*}{$\begin{array}{l}\text { U.S. Geological } \\
\text { Survey station } \\
\text { number }\end{array}$} & \multirow[b]{2}{*}{ Comments } \\
\hline Branch & Section & & \\
\hline 8 & 2 & 040871454 & Water Street bridge, Milwaukee River \\
\hline 6 & 2 & N/A & Menomonee River at mouth \\
\hline 7 & 2 & N/A & Milwaukee River at Michigan Street \\
\hline 9 & 2 & N/A & Kinnickinnic River at mouth \\
\hline 12 & 2 & 04087170 & Milwaukee River at mouth \\
\hline
\end{tabular}

$N / A=$ none available 
when the functional values of segment-geometry parameters are evaluated. The value of these weighting factors may vary from 0.00 to 1.00 , but model computational stability is only assured when values of theta and chi are equal to or greater than 0.6 and 0.5 , respectively (Schaffranek and others, 1981). Use of a value of 1.0 for these factors may dampen the actual fluctuation amplitude of stage and discharge. Simulation results for this study were obtained using a value of 0.7 for theta and 0.6 for chi, and yield good agreement with recorded stage values, generally to within $0.1 \mathrm{ft}$.

The factor that has the greatest effect on the model's simulated results is the value of the stage boundary input data for the Jones Island channel site. These values are not actually model parameters and, therefore, are not subject to calibration. It is worth noting, however, that even a small change in the boundary stage value results in a large change in discharge. For example, a $0.10-\mathrm{ft}$ change in stage results in a $1,200 \mathrm{ft}^{3} / \mathrm{s}$ change in a 5 -minute discharge at Jones Island. This magnitude of model sensitivity overwhelms any errors that may be caused by incorrect channel roughness factors or momentum coefficients. Even though there are errors in the Jones Island Channel stage values that affect the accuracy of the 5-, 15-, and 60-minute discharges, they do not materially affect the average daily discharge computations.

\section{Comparison of Discharge Computations Using Various Computation Intervals}

Model simulations were made for a 13-day event period (March 28-April 9, 1983) using 5-, 15-, and 60-minute computation intervals to compare simulated discharge results. Table 2 compares the total flow entering the upstream estuary tributaries with the dis?harge computed by the model for the mouth of the Milwaukee River at Jones Island. Average daily discharge at the Milwaukee River mouth computed by the model was in good agreement with that entering the estuary at the Survey gaging stations. This is to be expected unless the estuary volume is incorrectly represented by channel geometry. Discharge at the gaging stations was computed using standard U.S. Geological Survey mathods (U.S. Geological Survey, 1968a, 1968b, 1969, and 1983).

The model was not particularly sensitive to th? computation interval used in regard to the average daily discharge computed. Computed average daily dis harge results were consistently within 2 percent of each other regardless of which computation interval was used. However, this does not assure that any given 5-, 15-, or 60 -minute discharge computation is correct. The results shown in table 3 indicate a considerable variatior in the daily average maximum and minimum discharge values computed using different computation intervals.

The simulated discharge extremes shown in table 3 indicate that use of a 5-minute computation interval gave an average minimum discharge of $6,766 \mathrm{ft}^{3} / \mathrm{s}$ upstream, but use of a 60 -minute interval gave an average minimum of $1,147 \mathrm{ft}^{3} / \mathrm{s}$ downstream in the Jones Island crannel. Results of using a 5-minute computation interval indicates that upstream flow occurs sometime during every day. Of course, it must be kept in mind that these simrlated maximum and minimum flows actually represent the average flow computed for a 5-, 15-, or 60-minute interval, not an instanteous value. Use of a 5-minute com-

Table 2. Comparison of daily average discharge computations, March 28-April 9, 1983

[All values in cubic feet per second]

\begin{tabular}{|c|c|c|c|c|c|c|c|}
\hline \multirow{3}{*}{ Date } & \multicolumn{4}{|c|}{ Discharge at gaging stations } & \multirow{2}{*}{\multicolumn{3}{|c|}{$\begin{array}{l}\text { Di scharge at Milwaukee River novth } \\
\text { (Jones Island) computed by node } 1 \\
\text { using conputation interval of: }\end{array}$}} \\
\hline & \multirow{2}{*}{$\begin{array}{l}\text { Mil I waukee } \\
\text { River } \\
04087010\end{array}$} & \multirow{2}{*}{$\begin{array}{l}\text { Menomonee } \\
\text { River } \\
04087138\end{array}$} & \multirow{2}{*}{$\begin{array}{l}\text { Kinnickinnic } \\
\text { River } \\
04087159\end{array}$} & \multirow[b]{2}{*}{$\begin{array}{c}\text { Three river } \\
\text { total }\end{array}$} & & & \\
\hline & & & & & 5-sinutes & 15-minutes & $60-n$ inutes \\
\hline Mar. 28 & 761 & 171 & 39 & 971 & 1.080 & 1,080 & 1,090 \\
\hline Mar. 29 & 817 & 159 & 34 & 1,010 & 1,020 & 1,020 & 1,010 \\
\hline Mar. 30 & 833 & 185 & 41 & 1,069 & 1,090 & 1,090 & 1.09 \\
\hline Mar. 31 & 980 & 318 & 43 & 1,341 & 1,380 & 1,370 & $1,3 \cap n$ \\
\hline Apr. 1 & 1,200 & 508 & 52 & 1,760 & 1,770 & 1.770 & $1,7 \backsim$ \\
\hline Apr. 2 & 2,980 & 2,390 & 525 & 5,895 & 5,690 & 5,710 & $5,7^{\circ} 0$ \\
\hline Apr. 3 & 3,490 & 1,650 & 143 & 5,283 & 5,300 & 5,290 & $5,2^{\sim} 0$ \\
\hline Apr. 4 & 3,170 & 1,090 & 37 & 4.297 & 4.300 & 4.310 & $4.2^{\circ} 0$ \\
\hline Apr . 5 & 3,050 & 907 & 24 & 3,981 & 3,950 & 3,940 & 3,910 \\
\hline Apr. 6 & 3,060 & 772 & 37 & 3,869 & 3,860 & 3,860 & $3,8 \% 0$ \\
\hline Apr. 7 & 3,010 & 625 & 22 & 3,657 & 3,760 & 3,750 & 3,740 \\
\hline Apr. 8 & 2,790 & 476 & 17 & 3,283 & 3,230 & 3,210 & $3,2 \div 0$ \\
\hline Apr. 9 & $\underline{3,120}$ & 1,020 & $\underline{249}$ & 4,389 & 4,310 & 4,360 & $4,3 \backsim n$ \\
\hline $\begin{array}{l}\text { Average } \\
\text { discharge }\end{array}$ & 2,250 & 791 & 97 & 3,139 & 3,134 & 3.135 & 3,140 \\
\hline
\end{tabular}


Table 3. Comparison of maximum and minimum model discharge computations. Milwaukee River at mouth (Jones Island channel). March 28-April 9, 1983

[Negative discharges indicate upstream flow; values are in cubic feet per second]

\begin{tabular}{|c|c|c|c|c|c|c|}
\hline \multirow{2}{*}{ Date } & \multicolumn{5}{|c|}{ Discharge } & \multirow[b]{2}{*}{$\begin{array}{l}\text { interva l } \\
\text { Maximum }\end{array}$} \\
\hline & $\begin{array}{l}\text { 5-minute } \\
\text { Minimum }\end{array}$ & $\begin{array}{c}\text { interval } \\
\text { Maximum }\end{array}$ & $\begin{array}{l}\text { 15-minute } \\
\text { Minimum }\end{array}$ & $\begin{array}{l}\text { interval } \\
\text { Maximum }\end{array}$ & $\begin{array}{l}\text { 60-minute } \\
\text { Minimum }\end{array}$ & \\
\hline Mar. 28 & $-5,992$ & 7,739 & $-3,641$ & 6,632 & +132 & 2,157 \\
\hline Mar. 29 & $-3,327$ & 6.566 & $-1,688$ & 3,648 & -255 & 2,262 \\
\hline Mar. 30 & $-6,482$ & 8,277 & $-3,666$ & 4,710 & -237 & 2,571 \\
\hline Mar. 31 & $-3,652$ & 4,876 & $-1,056$ & 3,619 & -384 & 2,123 \\
\hline Apr. 1 & $-6,163$ & 8,136 & $-4,113$ & 6,435 & +844 & 3,053 \\
\hline Apr. & $-4,673$ & 17,150 & $-1,303$ & 14.815 & $+1,183$ & 8,818 \\
\hline Apr. & -794 & 11,891 & $+1,555$ & 8,275 & $+4,297$ & 6,975 \\
\hline Apr. & -7.002 & 19,185 & $-6,192$ & 13,041 & +1.931 & 6,048 \\
\hline Apr. 5 & -12.381 & 18,753 & $-3,921$ & 12,461 & $+1,766$ & 8,354 \\
\hline Apr. 6 & $-6,043$ & 18,544 & $-3,523$ & 11,437 & +1.834 & 6,887 \\
\hline Apr. & $-12,804$ & 20,191 & $-4,186$ & 11,892 & +788 & 6,769 \\
\hline Apr. 8 & $-7,065$ & 3,233 & $-2,884$ & 9,374 & +1.254 & 4,526 \\
\hline Apr. 9 & $-11,577$ & 17,494 & $-5,544$ & 14,340 & +984 & 8,385 \\
\hline $\begin{array}{l}\text { Average } \\
\text { discharge }\end{array}$ & $-6,766$ & 12,464 & $-3,089$ & 9,283 & 1,147 & 5,148 \\
\hline
\end{tabular}

putation interval is recommended if simulation of rapidly changing, unsteady-flow conditions is of importance. The use of a 60-minute computation interval would fail to indicate that upstream flow occurs during most days.

\section{Comparison of Simulated and Recorded Stage}

An important method of calibrating the Milwaukee Harbor Estuary branch-network model involved comparison of the simulated and recorded stage at the Water Street Bridge on the Milwaukee River. This site (Branch 8 , cross section 2, pl. 1) was selected because of its proximity to the confluence of the Milwaukee and Menomonee Rivers. Figure 4 is a graph of simulated stage as a function of recorded stage at Water Street for September 8, 1983. Five-minute stage records from the Milwaukee River at mouth (Jones Island channel) site were used as the downstream external-boundary condition.

Figure 4 represents a typical graph comparing simulated and recorded stage. Most stages simulated by the calibrated model are within $0.06 \mathrm{ft}$ of recorded stages. There is a notable 5-minute timing error in the peak and trough values or when stage is changing rapidly; this timing error results in up to a $0.1 \mathrm{ft}$ stage error. This timing error may be the result of the clocks at Jones Island and Water Street being somewhat out of synchronization at times. The flat peak recorded at Water Street between 0845 and 0855 probably is the result of a recorder malfunction, which can occur during periods when stage oscillates rapidly; then, the recorder locks at a given reading until the oscillations slow or abate. Rapid oscilla- tions of the water surface can be caused by heavy wind and wave action or by the passage of large vessels. This type of malfunction also may have occurred from 0900 to 0905 . The stage plot comparison in fig ure 4 appears quite good given the probable errors in the recorded stages.

\section{Comparison of Simulated and Measured Discharge}

Discharge measurements were made in the Jones Island channel in an attempt to obtain data to compare with the discharges computed by the model. Five such attempts were made. Discharge measurements were made from an anchored 20-ft boat using a Neil-Brown Instrument Systems (NBIS) acoustical velocity meter. ${ }^{2}$ The channel cross section was divided into 10 subsections for measurement purposes. Discharge measurements were made in the early morning on calm days to minimize wind and wave effects on the boat. Unfortunately, discharge conditions were so unsteady that it was impossible to complete a cross-sectic nal discharge measurement before a change in flow oncurred. The simultaneous use of several NBIS meters would be required to make an adequate discharge measurement in the channel. The large cross-sectional area involved (typically $14,800 \mathrm{ft}^{2}$ ) and the low average cross-sectional velocity $(0.0$ to $0.3 \mathrm{ft} / \mathrm{s})$ further compounded measurement errors. Both cross-sectional and depth-related differences in flow direction were present during each discharge measurement. Therefore, it was concluded that the five discharge measurements made should not be used for model-calibration purposes. However, the velo-

\footnotetext{
2 Use of brand names in this report is for descriptive purposes only and does not constitute endorsement by the U.S. Geological Survey.
} 


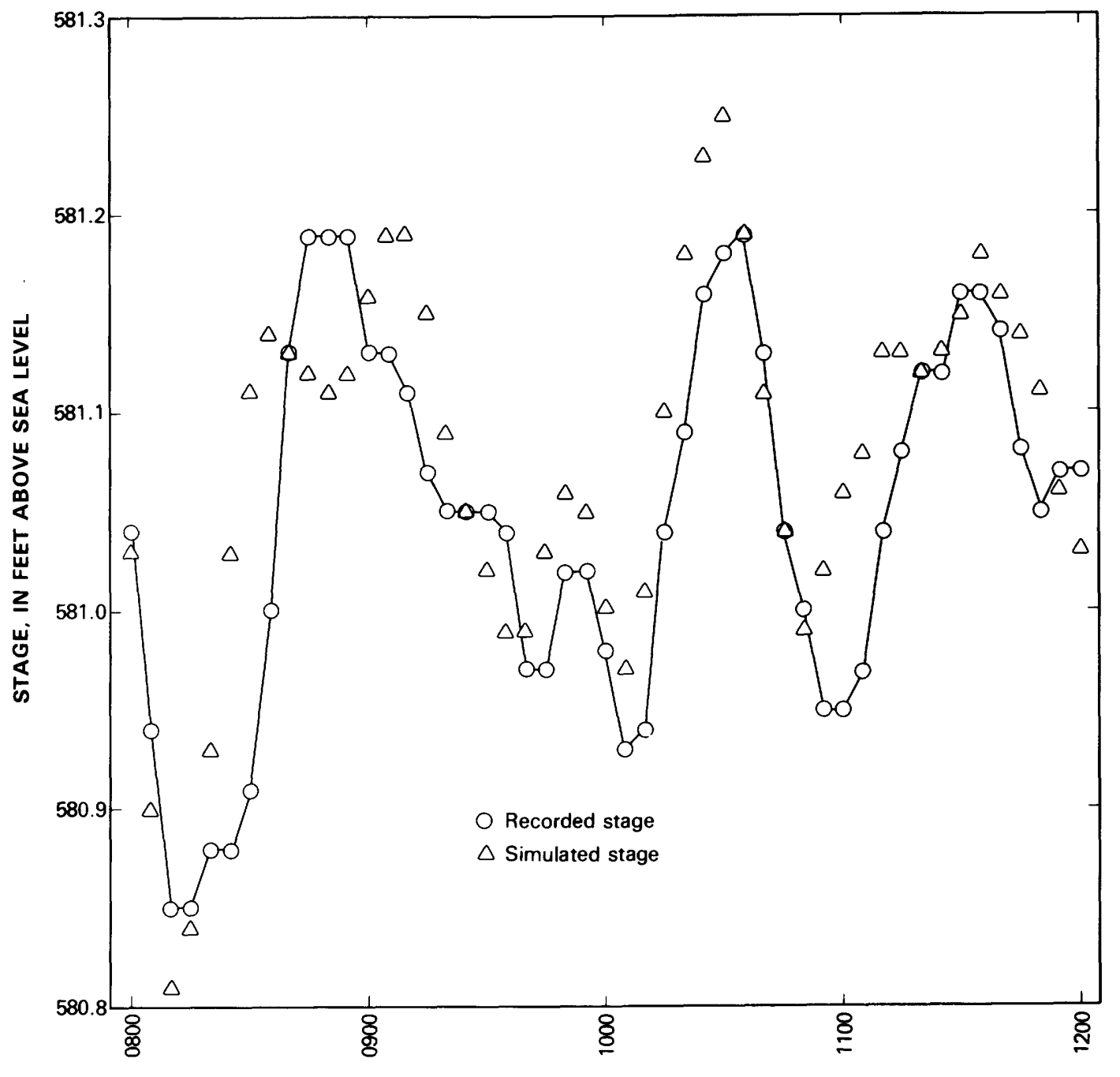

TIME, 2400-HOUR CLOCK

Figure 4. Comparison of simulated and recorded stage plots at Water Street, September 8, 1983.

city data collected as part of the discharge measurements usually indicated the same net flow direction lupstream or downstreaml at a given time as computed by the model.

\section{SIMULATION OF SELECTED FLOW EVENTS}

Six flow periods were simulated using the Milwaukee Harbor Estuary branch-network model. Simulations were made using 5- or 15-minute computation intervals. The simulated periods coincide with periods when intensive water-quality-sampling efforts were made as part of the comprehensive estuary investigation. The six periods simulated are November 7-12, 1982; March 28-April 9, 1983; August 9-14, 1983; September 10-14, 1983; October 10-20, 1983; and February 10-21, 1984. Tables 4 through 9 present the daily maximum, minimum, and average discharge at four key locations in the estuary (table 1). These four cross sections are shown on plate
1 and indicated on the tables as Menomonee Ri 'er at mouth, Milwaukee River at Michigan Street, Kinrickinnic River at mouth; and the Milwaukee River at mouth (Jones Island). The results shown in tables 4 thro'sgh 9 were computed by the model using a 15-minute computation interval.

Discharges for the period September 20 throuch October 10,1983 , were simulated using a 60 -minute computation interval. The results of this simulation are shown in table 10.

The daily discharge extremes generally occur at the same time throughout the estuary - that is, the maximum flow during the day will tend to occur at approximately the same time at all cross sections throughout the estuary. There is a similar nearly-simultaneous occurrence of minimum (maximum upstream) flows as well because of the extremely powerful Lake Michigan seiche effect and the relatively short wave traveltime required to reach the upstream limits of the estuary. 
Table 4. Simulation of Milwaukee Harbor Estuary discharge, November 7-12, 198?

[Negative discharge indicates upstream flow; values are in cubic feet per second]

\begin{tabular}{|c|c|c|c|c|c|c|c|c|c|c|c|c|}
\hline \multirow{2}{*}{ Date } & \multicolumn{3}{|c|}{$\begin{array}{l}\text { Menomonee River at wouth } \\
\text { Branch 6, Cross Section } 2\end{array}$} & \multicolumn{3}{|c|}{$\begin{array}{c}\text { Milwaukee River at Michigan Street } \\
\text { Branch } 7 \text {, Cross Section } 2\end{array}$} & \multicolumn{3}{|c|}{$\begin{array}{l}\text { Kinnickinnic River at mouth } \\
\text { Branch } 9, \text { Cross Section } 2\end{array}$} & \multicolumn{3}{|c|}{$\begin{array}{l}\text { Milwaukee River at mouth } \\
\text { Branch } 12 \text {, Cross section } 2\end{array}$} \\
\hline & Mininum & Mean & Maximum & Minimun & Mean & Maximum & Minimun & Mean & Maximun & Minimum & Mean & Maximum \\
\hline Nov. 7 & -634 & 29.3 & 626 & 206 & 555 & 942 & -90 & 6.6 & 110 & $-1,935$ & 559 & 3.415 \\
\hline Nov. 8 & $-1,221$ & 30.4 & 1,225 & -344 & 458 & 1,155 & -161 & 7.5 & 219 & $-3,884$ & 488 & 8,082 \\
\hline Nov. 9 & $-2,415$ & 178 & 1,742 & -970 & 527 & 1,504 & -396 & 76.5 & 488 & $-10,885$ & 719 & 11.194 \\
\hline Nov. 10 & $-2,345$ & 162 & 2,550 & -986 & 525 & 1.995 & -245 & 28.6 & 352 & $-8,434$ & 755 & 9,474 \\
\hline Nov. 11 & $-1,172$ & 169 & 1,234 & -225 & 603 & 1,420 & -240 & 53.2 & 304 & $-8,338$ & 838 & 5,956 \\
\hline Nov. 12 & $-1,793$ & 389 & 2,589 & -22.7 & 1,243 & 2,884 & -207 & 138 & 810 & -6.932 & 1,759 & 11,019 \\
\hline
\end{tabular}

Table 5. Simulation of Milwaukee Harbor Estuary discharge, March 28-April 9, 1983

[Negative discharge indicates upstream flow; values are in cubic feet per second]

\begin{tabular}{|c|c|c|c|c|c|c|c|c|c|c|c|c|}
\hline \multirow{2}{*}{ Date } & \multirow{2}{*}{$\begin{array}{l}\begin{array}{l}\text { Menomonee } \\
\text { Branch 6, }\end{array} \\
\text { Mininum }\end{array}$} & \multicolumn{2}{|c|}{$\begin{array}{l}\text { River at mouth } \\
\text { Cross Section } 2\end{array}$} & \multicolumn{3}{|c|}{$\begin{array}{l}\text { Milwaukee River at Michigan Street } \\
\text { Branch } 7 \text {, Cross Section } 2\end{array}$} & \multicolumn{3}{|c|}{$\begin{array}{l}\text { Kinnickinnic River at mouth } \\
\text { Branch } 9 \text {, Cross Section } 2\end{array}$} & \multicolumn{3}{|c|}{$\begin{array}{l}\text { Milwaukfe River at mouth } \\
\text { Branch 12, Cross section } 2\end{array}$} \\
\hline & & Mean & Maximum & Minimum & Mean & Maximui & Minimum & Mean & Maximum & Minimun & Mean & Maximun \\
\hline Mar. 28 & -574 & 210 & 1,401 & 282 & 774 & 1,319 & -143 & 41.9 & 240 & $-3,641$ & 1.082 & 8.632 \\
\hline Mar. 29 & -342 & 173 & 972 & 514 & 816 & 1.316 & -76 & 33.6 & 144 & $-1,688$ & 1.021 & 3.648 \\
\hline Mar. 30 & -519 & 218 & 958 & 355 & 834 & 1,276 & -123 & 40.7 & 188 & $-3,666$ & 1,088 & 4,710 \\
\hline Mar. 31 & -74.8 & 349 & 814 & 699 & 980 & 1,250 & -53.7 & 42.7 & 124 & $-1,056$ & 1,374 & 3,619 \\
\hline Apr. $\quad 1$ & -782 & 534 & 1,591 & 402 & 1.198 & 1,865 & -182 & 52.1 & 246 & $-4,113$ & 1,770 & 6,435 \\
\hline Apr. 2 & -88 & 2,214 & 4,497 & 1,060 & 2,988 & 4.458 & -15.9 & 525 & 1,226 & -1.303 & 5,710 & 14.815 \\
\hline Apr. & +538 & 1,616 & 2,643 & 2,853 & 3,497 & 4,106 & -56.3 & 143 & 389 & +1.555 & 5,290 & B. 275 \\
\hline Apr & $-1,038$ & 1,075 & 2,942 & 2,039 & 3,174 & 4,211 & -326 & 37.3 & 392 & $-6,192$ & 4,306 & 13,041 \\
\hline Apr. & -842 & 907 & 1,923 & 2,124 & 3,047 & 3,662 & -265 & 23.1 & 322 & -3.921 & 3,939 & 12.461 \\
\hline Apr. & -803 & 774 & 2,480 & 2,184 & 3,055 & 4,096 & -260 & 36.2 & 303 & $-3,523$ & 3,858 & 11,437 \\
\hline Apr. 7 & $-1,132$ & 664 & 2,482 & 1,968 & 3.016 & 4.076 & -244 & 23.5 & 302 & $-4,186$ & 3,748 & 11,892 \\
\hline Apr. 8 & -648 & 490 & 1,822 & 409 & 2,752 & 4,524 & -212 & 14.9 & 214 & $-2,884$ & 3,213 & 9.374 \\
\hline Apr. 9 & $-1,905$ & 959 & 3,042 & 1,172 & 3,133 & 4,494 & -332 & 249 & 946 & -5.544 & 4,360 & 14,340 \\
\hline
\end{tabular}

Table 6. Simulation of Milwaukee Harbor Estuary discharge, August 9-14, 198'

[Negative discharge indicates upstream flow; values are in cubic feet per second]

\begin{tabular}{|c|c|c|c|c|c|c|c|c|c|c|c|c|}
\hline \multirow{2}{*}{ Date } & \multirow{2}{*}{$\begin{array}{l}\text { Menomonee } \\
\text { Branch } 6 \text {, } \\
\text { Mininum }\end{array}$} & \multicolumn{2}{|c|}{$\begin{array}{l}\text { River at mouth } \\
\text { Cross Section } 2\end{array}$} & \multicolumn{3}{|c|}{$\begin{array}{c}\text { Mi lwaukee River at Michigan Street } \\
\text { Branch 7, Cross Section } 2\end{array}$} & \multicolumn{3}{|c|}{$\begin{array}{l}\text { Kinnickinnic River at mouth } \\
\text { Branch } 9 \text {, Cross Section } 2\end{array}$} & \multicolumn{3}{|c|}{$\begin{array}{l}\text { Milwauker River at mouth } \\
\text { Branch } 12 \text {, Cross section } 2\end{array}$} \\
\hline & & Mean & Maximun & Minimum & Mean & Maxinum & Minimum & Mean & Maxinum & Mininum & Mean & Maximum \\
\hline Aug. $\quad 9$ & -530 & 20.8 & 1.525 & -213 & 108 & 638 & -87.5 & 12.0 & 200 & $-2,833$ & 138 & 4,478 \\
\hline Aug. 10 & $-2,018$ & 85.4 & 1,740 & $-1,118$ & 150 & 1,252 & -256 & 116 & 948 & $-8,843$ & 389 & 8.218 \\
\hline Aug. 11 & $-2,523$ & 34.5 & 2,033 & $-1,365$ & 140 & 1,422 & -347 & 27.2 & 366 & $-10,939$ & 152 & 9,689 \\
\hline Aug. 12 & $-1,116$ & 27.8 & 988 & -560 & 124 & 708 & -190 & 11.6 & 195 & $-5,426$ & 191 & 4,465 \\
\hline Aug. 13 & -697 & 21.5 & 1,065 & -340 & 108 & 739 & -122 & 9.4 & 173 & $-2,756$ & 148 & 5,115 \\
\hline Aug. 14 & -485 & 18.5 & 557 & -206 & 101 & 411 & -71.5 & 9.0 & 123 & $-2,585$ & 134 & 3,278 \\
\hline
\end{tabular}

Table 7. Simulation of Milwaukee Harbor Estuary discharge, September 10-14, 1983

[Negative discharge indicates upstream flow; values are in cubic feet per second]

\begin{tabular}{|c|c|c|c|c|c|c|c|c|c|c|c|c|}
\hline \multirow{2}{*}{ Date } & \multicolumn{3}{|c|}{$\begin{array}{l}\text { Menononee River at mouth } \\
\text { Branch } 6 \text {, Cross Section } 2\end{array}$} & \multicolumn{3}{|c|}{$\begin{array}{c}\text { Milwaukee River at Michigan Street } \\
\text { Branch } 7 \text {, Cross Section } 2\end{array}$} & \multicolumn{3}{|c|}{$\begin{array}{l}\text { Kinnickinnic River at nouth } \\
\text { Branch 9, Cross Section } 2\end{array}$} & $\begin{array}{r}\text { Milwauke } \\
\text { Branch } 12\end{array}$ & $\begin{array}{l}\text { River } \\
\text { Cross }\end{array}$ & $\begin{array}{l}\text { at nouth } \\
\text { section } 2\end{array}$ \\
\hline & Mininue & Mean & Maximun & Mininue & Mean & Maximun & Mininum & Mean & Maxinum & Mininum & Mean & Maximun \\
\hline Sept. 10 & $-1,090$ & 101 & 1,274 & -376 & 264 & 1,242 & -180 & 47.5 & 378 & $-6,641$ & 386 & 6,499 \\
\hline Sept. 11 & $-1,139$ & 64.6 & 1,225 & -538 & 207 & 879 & -176 & 13.2 & 242 & $-4,584$ & 325 & 7.726 \\
\hline Sept. 12 & $-1,891$ & 20.1 & 2,270 & $-1,026$ & 155 & 1,509 & -296 & 7.6 & 366 & $-8,122$ & 177 & 10,062 \\
\hline Sept. 13 & -871 & 26.7 & 713 & -334 & 172 & 566 & -185 & 7.7 & 145 & $-5,415$ & 202 & 4,180 \\
\hline Sept. 14 & -751 & 16.4 & 574 & -315 & 153 & 476 & -125 & 6.7 & 127 & $-3,181$ & 164 & 3.526 \\
\hline
\end{tabular}


Table 8. Simulation of Milwaukee Harbor Estuary discharge, October 10-20, 1983

[Negative discharge indicates upstream flow; values are in cubic feet per second]

\begin{tabular}{|c|c|c|c|c|c|c|c|c|c|c|c|c|}
\hline \multirow{2}{*}{ Date } & \multicolumn{3}{|c|}{$\begin{array}{l}\text { Menomonee River at mouth } \\
\text { Branch } 6 \text {, Cross Section } 2\end{array}$} & \multicolumn{3}{|c|}{$\begin{array}{c}\text { Milwaukee River at Michigan street } \\
\text { Branch 7, Cross Section } 2\end{array}$} & \multicolumn{3}{|c|}{$\begin{array}{l}\text { Kinnickinnic River at wouth } \\
\text { Branch 9, Crose Section } 2\end{array}$} & \multicolumn{3}{|c|}{$\begin{array}{l}\text { Milwaukee River a* south } \\
\text { Branch } 12 \text {, Cross section } 2\end{array}$} \\
\hline & Mininu & Mean & Maximua & Minimua & Mean & Maximun & Minimun & Mean & Maxi num & Minimui & Mean & Maxinum \\
\hline Oct. 10 & -736 & 39.2 & 1,251 & 52.9 & 364 & 689 & -103 & 7.7 & 105 & $-2,313$ & 399 & 2.923 \\
\hline oct. 11 & -517 & 46.2 & 804 & -18.5 & 350 & 795 & -107 & 8.0 & 144 & $-2,584$ & 406 & 3,983 \\
\hline oct. 12 & -1.456 & 199 & 1,686 & -515 & 502 & 1,411 & -262 & 66.0 & 384 & $-6,323$ & 764 & 7,988 \\
\hline oct. 13 & $-1,510$ & 85.7 & 2,029 & -529 & 433 & 1,622 & -323 & 14.1 & 241 & $-9,145$ & 592 & 8,102 \\
\hline Oct. 14 & -900 & 48.7 & 999 & -72.7 & 517 & 1,062 & -145 & 9.1 & 164 & -4.216 & 580 & 5,505 \\
\hline oct. 15 & -860 & 24.7 & 1,131 & +24.8 & 546 & 1,187 & -145 & 5.3 & 192 & -4.059 & 537 & 5.335 \\
\hline Oct. 16 & -601 & 32.3 & 747 & 117 & 474 & 936 & -93.5 & 6.4 & 138 & $-2,170$ & 511 & 4,118 \\
\hline oct. 17 & -774 & 35.9 & 782 & -26.2 & 450 & 914 & -115 & 8.2 & 133 & $-3,366$ & $\mathbf{5 1 0}$ & 4.272 \\
\hline oct. 18 & -807 & 13.7 & 648 & -95.7 & 408 & 783 & -108 & 5.0 & 118 & $-2,916$ & 387 & 3,490 \\
\hline oct. 19 & $-1,350$ & 25.3 & 1,095 & -420 & 381 & 1,052 & -218 & 6.8 & 192 & $-6,836$ & 400 & 6.352 \\
\hline Oct, 20 & -1.386 & 30.6 & 1.412 & -550 & 351 & 1,149 & -198 & 12.8 & 304 & $-5,585$ & 390 & 7.545 \\
\hline
\end{tabular}

Table 9. Simulation of Milwaukee Harbor Estuary discharge, February 10-21, 1984

[Negative discharge indicates upstream flow; values are in cubic feet per second]

\begin{tabular}{|c|c|c|c|c|c|c|c|c|c|c|c|c|}
\hline \multirow{2}{*}{ Date } & \multicolumn{3}{|c|}{$\begin{array}{l}\text { Menomonee River at mouth } \\
\text { Branch 6. Cross Section } 2\end{array}$} & \multicolumn{3}{|c|}{$\begin{array}{l}\text { Milwaukee River at Michigan Street } \\
\text { Branch } 7 \text {, Cross Section } 2\end{array}$} & \multicolumn{3}{|c|}{$\begin{array}{l}\text { Kinnickinnic River at mouth } \\
\text { Branch 9, Cross Section } 2\end{array}$} & \multicolumn{3}{|c|}{$\begin{array}{l}\text { Milwaukee River at wouth } \\
\text { Branch } 12 \text {. Cross arntion } 2\end{array}$} \\
\hline & Mininum & Mean & Maximun & Minimum & Mean & Maximum & Minimuin & Mean & Maximun & Minimun & Wean & Maximum \\
\hline Feb. 10 & $-1,160$ & 84.0 & 4.692 & -71.8 & 308 & 705 & -95.8 & 11.8 & 185 & -2.211 & 408 & 7.802 \\
\hline Reb. 11 & -578 & 81.9 & 939 & -98.2 & 306 & 845 & -115 & 17.9 & 138 & $-3,238$ & 389 & 3,318 \\
\hline Peb. 12 & -578 & 423 & 2.057 & -84.0 & 532 & 1.429 & -56.9 & 127 & 393 & $-3,199$ & 1.064 & 5.377 \\
\hline Reb. 13 & -310 & 1.128 & 2.343 & 627 & 1,558 & 2,388 & -152 & 176 & 704 & $-4,318$ & 2.878 & 10,335 \\
\hline Peb. 14 & -289 & 780 & 1.757 & 1,380 & 1.937 & 2.590 & -150 & 29.0 & 233 & -2.020 & 2,729 & 9,121 \\
\hline Reb. 15 & -188 & 802 & 1.429 & 1.470 & 2,013 & 2,571 & -106 & 17.9 & 151 & -1.054 & 2,643 & 8.574 \\
\hline Reb. 16 & -1.033 & 479 & 1,598 & 1,552 & 2,293 & 3,034 & -234 & 14.3 & 288 & -2.987 & 2,764 & 10,073 \\
\hline Peb. 17 & $-1,001$ & 387 & 1,576 & 1.679 & 2,481 & 3,096 & -204 & 15.9 & 259 & $-2,234$ & 2,890 & 9,838 \\
\hline Reb. 18 & $-1,394$ & 340 & 1,714 & 1.272 & 2,377 & 3,173 & -196 & 34.8 & 331 & $-4,887$ & 2,758 & 10.400 \\
\hline Feb. 19 & -964 & 445 & 1.488 & 1,356 & 2,539 & 3,211 & -221 & 37.5 & 276 & $-3,219$ & 3,008 & 9,990 \\
\hline Feb. 20 & -138 & 348 & 1.133 & 2.048 & 2,419 & 2,933 & -81.9 & 18.2 & 145 & +298 & 2,816 & 6.298 \\
\hline Feb. 21 & -412 & 280 & 1,280 & 1,824 & 2,251 & 2.866 & -118 & 14.3 & 185 & $-1,293$ & 2,543 & 7,127 \\
\hline
\end{tabular}

Table 10. Simulation of Milwaukee Harbor Estuary discharge, September 20-October 10, 198`

[Negative discharge indicates upstream flow; values are in cubic feet per second]

\begin{tabular}{|c|c|c|c|c|c|c|c|c|c|c|c|c|}
\hline \multirow{2}{*}{ Date } & \multirow{2}{*}{$\begin{array}{l}\text { Menononee } \\
\text { Branch } 6 \text {, } \\
\text { Mininum }\end{array}$} & \multicolumn{2}{|c|}{$\begin{array}{l}\text { River at mouth } \\
\text { Cross Section } 2\end{array}$} & \multicolumn{3}{|c|}{$\begin{array}{l}\text { Mi I waukee River at Michigan street } \\
\text { Branch 7, Cross Section } 2\end{array}$} & \multicolumn{3}{|c|}{$\begin{array}{l}\text { Kinnickinnic River at wouth } \\
\text { Branch 9, Croses Section } 2\end{array}$} & \multicolumn{3}{|c|}{$\begin{array}{l}\text { Milwaukee River at wouth } \\
\text { Branch 12. Cross section } 2\end{array}$} \\
\hline & & Mean & Maxinun & Minimun & Mean & Maximum & Minimum & Mean & Maximun & Minimuan & Mean & Maximum \\
\hline Sept. 20 & $-1,048$ & 200 & 1.529 & +3.0 & 680 & 1,571 & -132 & 57.3 & 285 & $-5,044$ & 951 & 7,078 \\
\hline Sept. 21 & -308 & 112 & 669 & -28.7 & 488 & 829 & -52.4 & 13.4 & 102 & -1.563 & 621 & 3,271 \\
\hline Sept. 22 & -141 & 70.5 & 321 & +306 & 448 & 625 & -23.5 & 9.1 & 48.8 & -508 & 525 & 1,887 \\
\hline Sept. 23 & -146 & 55.4 & 260 & +182 & 312 & 427 & -20.9 & 9.3 & 42.1 & -542 & 387 & 1.358 \\
\hline Sept. 24 & -104 & 38.5 & 222 & 204 & 296 & 407 & -16.0 & 7.4 & 35.9 & -382 & 340 & 1,201 \\
\hline Sept. 25 & -196 & 137 & 415 & 139 & 427 & 707 & -18.9 & 36.4 & 110 & -833 & 610 & 1.871 \\
\hline Sept. 26 & -265 & 77.3 & 253 & 139 & 354 & 440 & -41.0 & 10.4 & 36.2 & -1.133 & 452 & 1,215 \\
\hline Sept. 27 & -55.9 & 53.1 & 182 & 282 & 343 & 421 & -8.2 & 8.5 & 29.0 & -121 & 395 & 1.004 \\
\hline Sept. 28 & -50.2 & 38.4 & 132 & 251 & 317 & 370 & -4.9 & 7.8 & 22.4 & -47.9 & 343 & 786 \\
\hline Sept. 29 & -42.4 & 41.2 & 135 & 228 & 286 & 340 & -4.3 & 8.9 & 23.1 & -51.2 & 347 & 769 \\
\hline Sept. 30 & -144 & 30.9 & 224 & 149 & 258 & 368 & -19.2 & 7.3 & 37.0 & -520 & 284 & 1,189 \\
\hline oct. 1 & -99.3 & 30.7 & 172 & 161 & 237 & 327 & -13.6 & 7.0 & 29.0 & -381 & 274 & 940 \\
\hline oct. 2 & -128 & 33.4 & 256 & 124 & 224 & 344 & -17.5 & 7.3 & 42.8 & -474 & 279 & 1.333 \\
\hline Oct. 3 & -145 & 22.8 & 499 & 107 & 203 & 486 & -19.0 & 18.3 & 107 & -523 & 200 & 2.400 \\
\hline Oct. 4 & -448 & 45.3 & 596 & -50.3 & 233 & 518 & -61.4 & 23.2 & 194 & $-2,008$ & 293 & 2.888 \\
\hline Oct. 5 & -300 & 47.7 & 482 & 22.7 & 247 & 486 & -42.4 & 11.8 & 78.9 & -1.234 & 366 & 2.400 \\
\hline Oct. 6 & -198 & 26.1 & 156 & 116 & 256 & 334 & -28.8 & 7.6 & 26.6 & -784 & 296 & 883 \\
\hline oct. 7 & -471 & 34.9 & 543 & -35.4 & 280 & 561 & -72.4 & 12.3 & 143 & -2.177 & 293 & 2.814 \\
\hline oct. 8 & -295 & 149 & 828 & 154 & 418 & 1,043 & -18.1 & 66.6 & 380 & $-1,404$ & 611 & 2,980 \\
\hline Oct. 9 & -145 & 50.0 & 258 & 239 & 342 & 497 & -21.3 & 9.3 & 42.9 & -474 & 433 & 1.481 \\
\hline Oct. 10 & -249 & 23.3 & 214 & 197 & 360 & 471 & -37.9 & 6.3 & 37.4 & -970 & 363 & 1,314 \\
\hline
\end{tabular}


The greatest range in discharge occurs in the Jones Island channel (the Milwaukee River mouth). Figure 5 shows a typical range of upstream and downstream discharge as simulated by the model. The model simula- tion shows a change in discharge from an $8,820 \mathrm{ft}^{3} / \mathrm{s}$ flow upstream to a $10,350 \mathrm{ft}^{3} / \mathrm{s}$ flow downstream within a half hour. This type of rapid reversal in flow direction is supported by observation of surface debris in the channel.

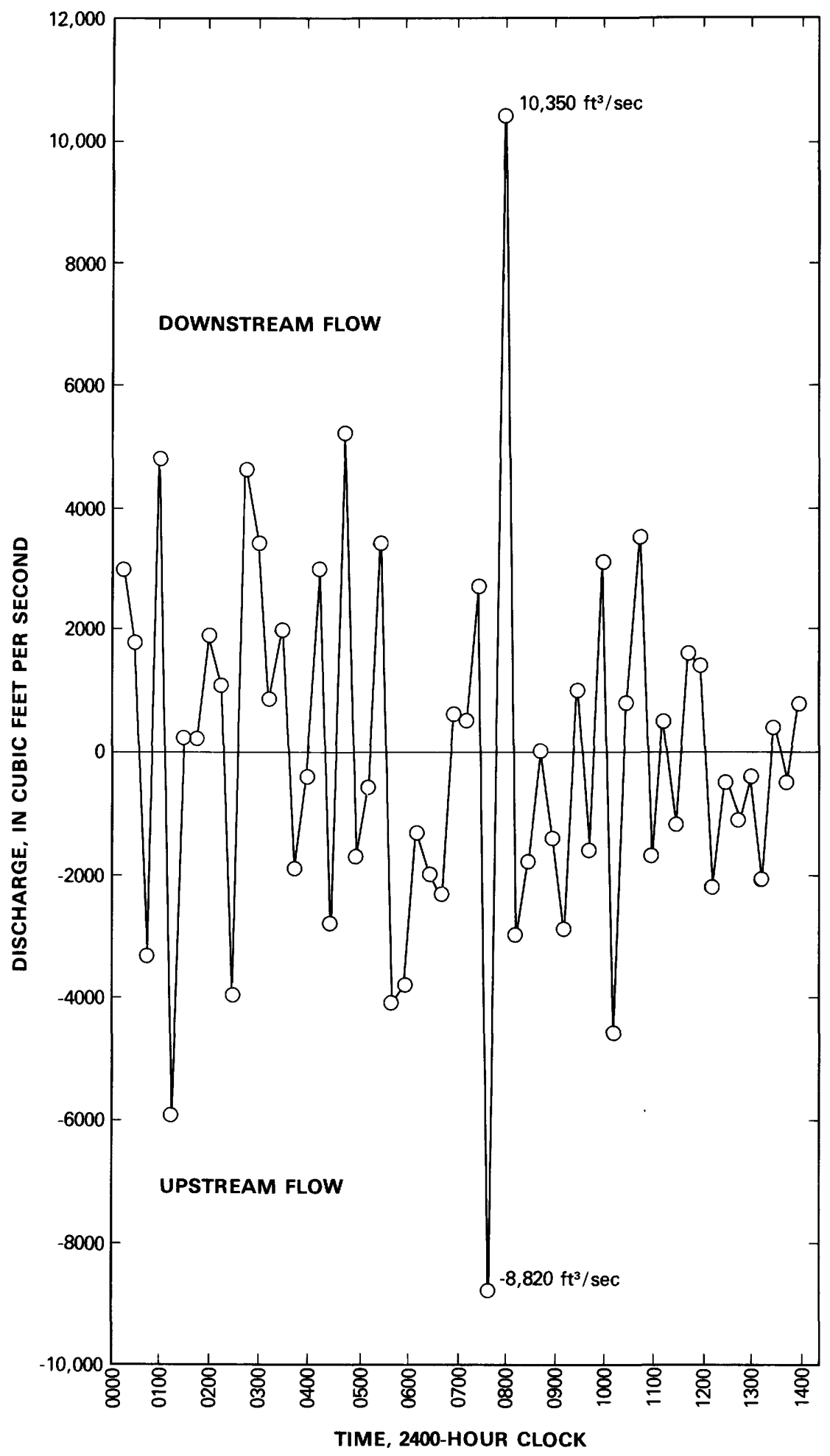

Figure 5. Simulated discharge for Milwaukee River at Jones Island, September 8, 1983. 
The magnitude of the flow reversal shown in figure 5 appears impressive, but the reversal duration is relatively short. It should also be noted that the associated velocity is on the order of only $0.7 \mathrm{ft} / \mathrm{s}$, and the volume of water moved is only about one-sixth of the volume of the Jones Island channel. In effect, the simulated results in figure 5 show that a plug of water would flow about 300 to 400 $\mathrm{ft}$ into the channel and then flow out again over a span of 20 minutes. Such a phenomenon has frequently been observed by U.S. Geological Survey personnel working at the Jones Island gage site. Floating objects have been noted to migrate repeatedly back and forth past the gage during maintenance visits.

One effect of this observed and simulated flowreversal phenomenon is that contaminated sediment may not be flushed out of the inner harbor as fast as might otherwise be expected. Increased sediment settlement may occur in the inner harbor during periods of rapid flow reversal when periods of upstream flow or zero net velocity exist.

\section{SUMMARY}

A one-dimensional finite-difference unsteady-flow model was applied to the Milwaukee Harbor Estuary. The model provides estimates of continuous discharge and stage at selected cross sections in the estuary. The model computes net average discharge at a cross section but cannot simulate the multilayered flow conditions known to occur in the estuary.

The model was calibrated by adjusting the Manning channel roughness coefficient, the momentum coefficient, and the finite-difference and geometry-weighting factors. Satisfactory agreement was obtained between average daily discharge computed at gaging stations and that computed by the model. Good agreement also was obtained between simulated and recorded stage at a key site in the estuary, generally within $0.1 \mathrm{ft}$. However, actual calibration based on comparison of simulated and measured discharge was not possible because of the difficulty in making discharge measurements under extremely unsteady flow conditions.
Six storm-runoff periods were simulated $\mathrm{t}:$ the model using 5- or 15-minute computation intervals. Results of using the shorter computational interval reflect the extremely unsteady flow conditions in the estuary. A short-duration upstream flow into the estuary' from Lake Michigan is a common occurrence that freq Iently is four times larger than the average daily downstream flow. The upstream-flow effect extends througho' It the entire length of the estuary.

\section{GLOSSARY}

Cubic feet per second $\left(\mathrm{ft}^{3} / \mathrm{s}\right)$. - A unit expressing rate of discharge. One cubic foot per second is equal to the discharge of a stream through a square cross section 1 foot wide and 1 foot deep at an avarage velocity of 1 foot per second. (Negative discharge values as used in this report indicate upstream flow.)

Gaging station. - A particular site on a river or reservoir where systematic time-series observations of gage height (water-surface elevation) or discharg? are recorded.

International Great Lakes Datum of 1955 (IGLD 1955'. - A vertical control datum used on the Great Lakes System. In the Milwaukee, Wis., area, add, about $1.3 \mathrm{ft}$ to convert elevations based on sea le'el to IGLD 1955. Exact conversion factors vary with latitude and elevation.

Manning's roughness coefficient. - A measure of tha frictional resistance exerted by a channel on flow.

Momentum coefficient. - A measure of the nonuniformity in velocity distribution through a channel cross section.

Lake seiche. - In this report, an oscillation of the surface of Lake Michigan over a period of a few minutes to a few hours as a result of atmospheric disturbances. 


\section{REFERENCES CITED}

Chow, V. T., 1959, Open channel hydraulics: McGrawHill Civil Engineering series, $680 \mathrm{p}$.

Harleman, D. R. F., and Stolzenbach, K. D., 1967, A model study of thermal stratification produced by condenser water discharge: Massachussetts Institute of Technology, Department of Civil Engineering, Hydrodynamics Lab Report No. 107. $100 \mathrm{p}$.

Holtschlag, D. J., 1981, Flow model of Saginaw River near Saginaw, Michigan: U.S. Geological Survey Open-File Report 81-1061, 20 p.

Schaffranek, R. W., Baltzer, R. A., and Goldberg, D. E., 1981, A model for simulation of flow in singular and interconnected channels: Techniques of WaterResources Investigations of the U.S. Geological Survey, Book 7, Chapter C3, 110 p.

Stedfast, D. A., 1982, Flow model of the Hudson River Estuary from Albany to New Hamburg, New York: U.S. Geological Survey Water-Resources Investigations Report 82-55, 69 p.
Southeastern Wisconsin Regional Planning Commission, 1981, Study design for the Milwaukee Harbor Estuary Comprehensive Water Resources Planning Program: Waukesha, Wis., 291 p.

U.S. Geological Survey, 1968a, Stage measurement at gaging stations: U.S. Geological Survey Techniques of Water-Resources Investigations, Book 3, Chapter A7, 28 p. 1968b, General procedure for gaging streams: U.S. Geological Survey Techniques of Water-Resources Investigations, Book 3, Chapter A6, 13 p. 1969, Discharge measurements at gazing stations: U.S. Geological Survey Techniques of WaterResources Investigations, Book 3, Chapter A8, $65 \mathrm{p}$.

1983, Computation of continuous records of streamflow: U.S. Geological Survey "echniques of Water-Resources Investigations, Book 3, Chapter A13, $53 \mathrm{p}$. 1984, Water data report WI 83-1: Water Resources Data, Wisconsin water year 1983, 352 p. 


\section{APPENDIX: LIST OF MODEL USER-INPUT CODE}

The following appendix contains the user-input code to run the U.S. Geological Survey Branch Network Model for the Milwaukee Harbor Estuary as described in this report and boundary conditions. This input list in- cludes the channel-geometry data and boundary conditions used in the model. See the computer-program-users manual (Schaffranek and others, 1981) for a complete explanation of this listing.
$/ /$ AG4 OWP4C JOB $(445512500$, BRANCH, 30,90$)$, 'LBHOUSE' , CLASS=D

/ /AG4 OWP4C JOB (445512500, BRANCH, 30,90), 'LBHOUSE', CLASS=D * \$\$FILE <SW>LEO>MILWAUKE>PROUT. DY830328-60MIN

JOBPARM F=PRIM

PROCLIB DD DSN=SCHAF. PROCLIB, DISP=SHR

$/$ BRANCH EXEC BRANCH, PROG $=$ BRANOO, ETIME $={ }^{\prime}(9,00)^{\prime}$,

/ GINAME='BALTZ. GPHINDXI. MILWAUKE',

/ DANAME $=1$ AG4 OWP4. DAYLTDDB
//BRNCH.FTO6FO01 DD SYSOUT=A
//BRNCH.FT07FOOI DD SYSOUT=A

/ SYSIN DD * //SYSIN DD *
MILWAUKEE HARBOR ESTUARY BRANCH NETWORK DISCHARGE MODEL WITH CANALS
FV 12137

MIV137

$60.710 .0 \quad 0.02$

.618

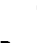

THIS MODEL SCHEMATIC HAS 12 BRANCHES AND 13 JUNCTIONS.

JUNCTION NO. 10 IS A DISCHARGE-DRIVEN EXTERNAL BOUNDARY FOR THE MENOMONEE RIVER.

JUNCTION NO.5 IS A DISCHARGE-DRIVEN EXTERNAL BOUNDARY FOR THE MILWAUKEE RIVER.

JUNCTION NO.8 IS A DISCHARGE-DRIVEN EXTERNAL BOUNDARY FOR THE KINNICKINNICK
THIS SIMULATION USES A 60-MINUTE TIME STEP WITH INPUT TDDB DISCHARGE DATA.

THIS SIMULATION USES A 60-MINUTE TIME STEP

TIME-VARYING WINDSPEED AND DIRECTION DATA IS NOT USED.
099 MENOMONEE RIVER FROM FALK DAM TO WEPCO

$581.47 \quad 213.0$
90.00

11575

575.0

$\begin{array}{ll}136.1 & 62.0 \\ 204.5 & 74.7\end{array}$

$\begin{array}{rr}204.5 & 74.7 \\ 299.0 & 132.3\end{array}$

150.9

$598.5 \quad 151.0$

$\begin{array}{ll}749.5 & 151.0\end{array}$

$1051.5 \quad 151.0$

$1202.5 \quad 151.0$

$\begin{array}{ll}1504.5 & 151.0\end{array}$

1597. $\quad 150.5$

1748.1150 .7

2050. 150.8

2200.151 .0

2352. 151.0

2503. 151.0

2805. 151.0

2956. 151.0

$\begin{array}{ll}3107 . & 151.0 \\ 3862 . & 151.0\end{array}$

213.0

2271. $\quad 140.5$

$2411 . \quad 140.7$

2552.140 .8

2693. 141.0

2975. 141.0

3116. 141.0

3257. 141.0

$3398 . \quad 141.0$

3539.0141 .0

3 MENOMONEE RIVER FROM WEPCO TO CANALS

183.0

1.00

$2271 . \quad 140.5$

2411 . 140.7

2552. 140.

2834 . 141.0

2975. 141.0

3116.0141 .0

3398. 141.0

3539.0141 .0

$\begin{aligned} 3680 . & \\ 183.0 & \end{aligned}$

141.0
5460.0

\section{0}

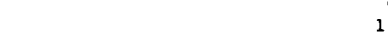

575.0

\subsection{0}

578.0
579.0

579.0
580.0

581.0
582.0

582.0
583.0
584.0

584.0
585.0

581.33

90.00

11

575.0
576.0

576.0
577.0

578.0
579.0

579.0
580.0

580.0
581.0

582.0

0000.0

$0.0240 \mathrm{E}$

0.0

0.0

$0.0240 E$

0.0

00000

584.0
585.0

585.0

$581.36 \quad 0.0$

90.0

575.0

576.0

577.0

579.

580.

581.0

582.0

583.0

584.0
585.0

581.33

11900

575.0

576.0

577.0
578.0

578.0

580.0

581.0

582.0
583.0
1.00

2666.

2816 .

3118.

3269 .

3571 .

3722 .

4024 .

4175 .

183.0

1.00

5479 .

5760.
6040.

6322.

6603.

788.

7446.

7727.

8008 .

HAN CANAL

1.00

1221. 130.1

1351. $\quad 130.4$

1613. $\quad 130.7$

744. $\quad 131.0$

1875.131 .0

2006.

2137.

2399 .

5.0

1.00

2668 .

2808 .

3090 .

3231 .

3372 .

3654 .

3654.
3795.
3936.
4077.

GENOMONEE CANA

1.00

2624.
2765.

2905.

3047.

3329 .

3470 .

3611.

3752.

3893.

5.0

2668.

2668.

2949.

3231 .

3231.

3372 .

3654 .
0.0

280.6

280.9

281.0

281.0

281.0

281.0
281.0

131.0

131.0

131.0

140.7

140.8

141.0

141.0

141.0

141.0

141.0

141.0

140.7

140.7
140.8

140.9

141.0

141.0

141.0
141.0

141.0

141.0

141.0

140.7

140.8

140.9

141.0

141.0

141.0
141.0

3300.0

0.0
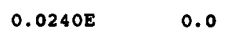

0.0

2290.0

$0.0240 \mathrm{E}$

0.0

$0^{11111}$

$0.0240 E$

0.0

0.0 


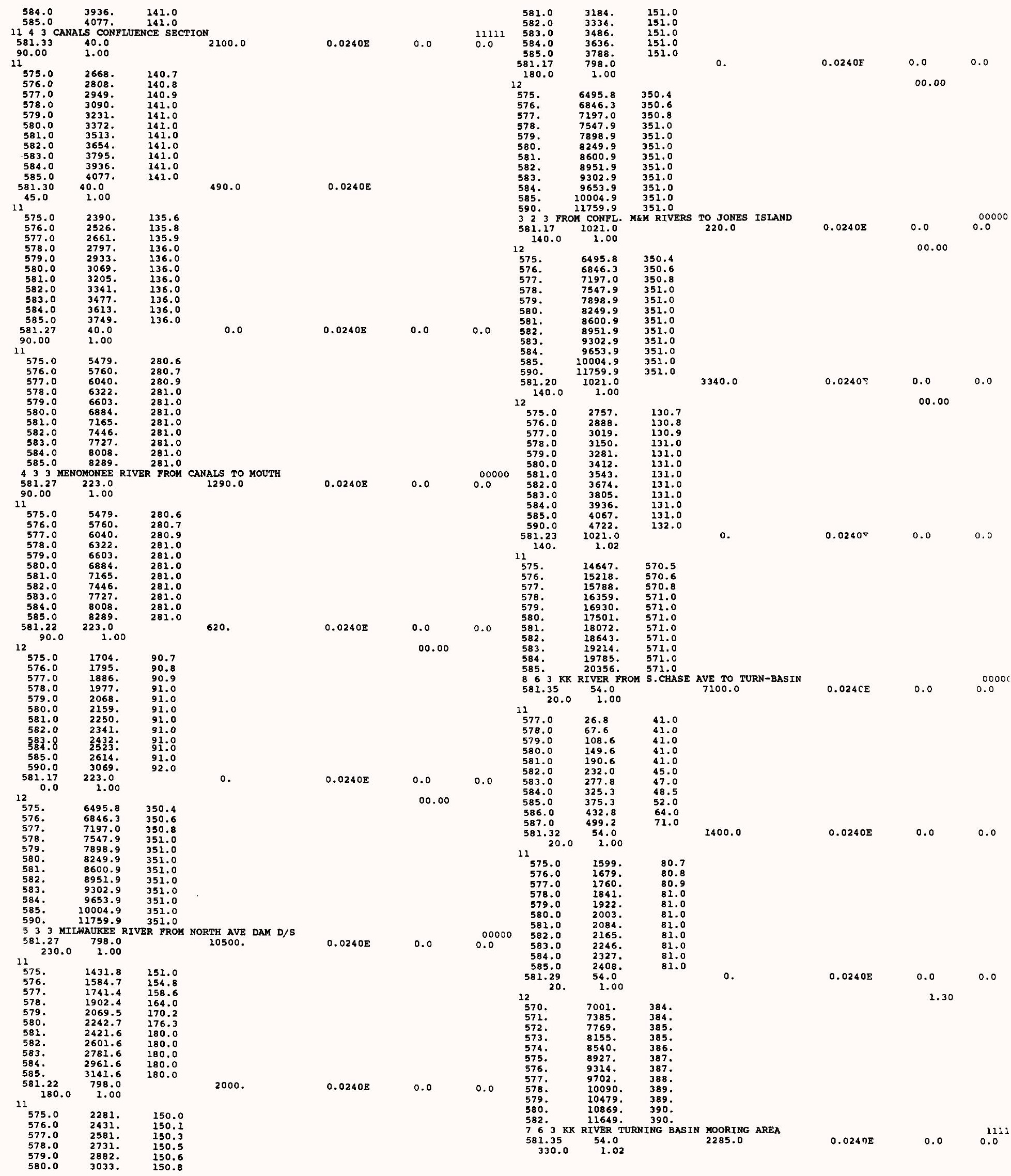




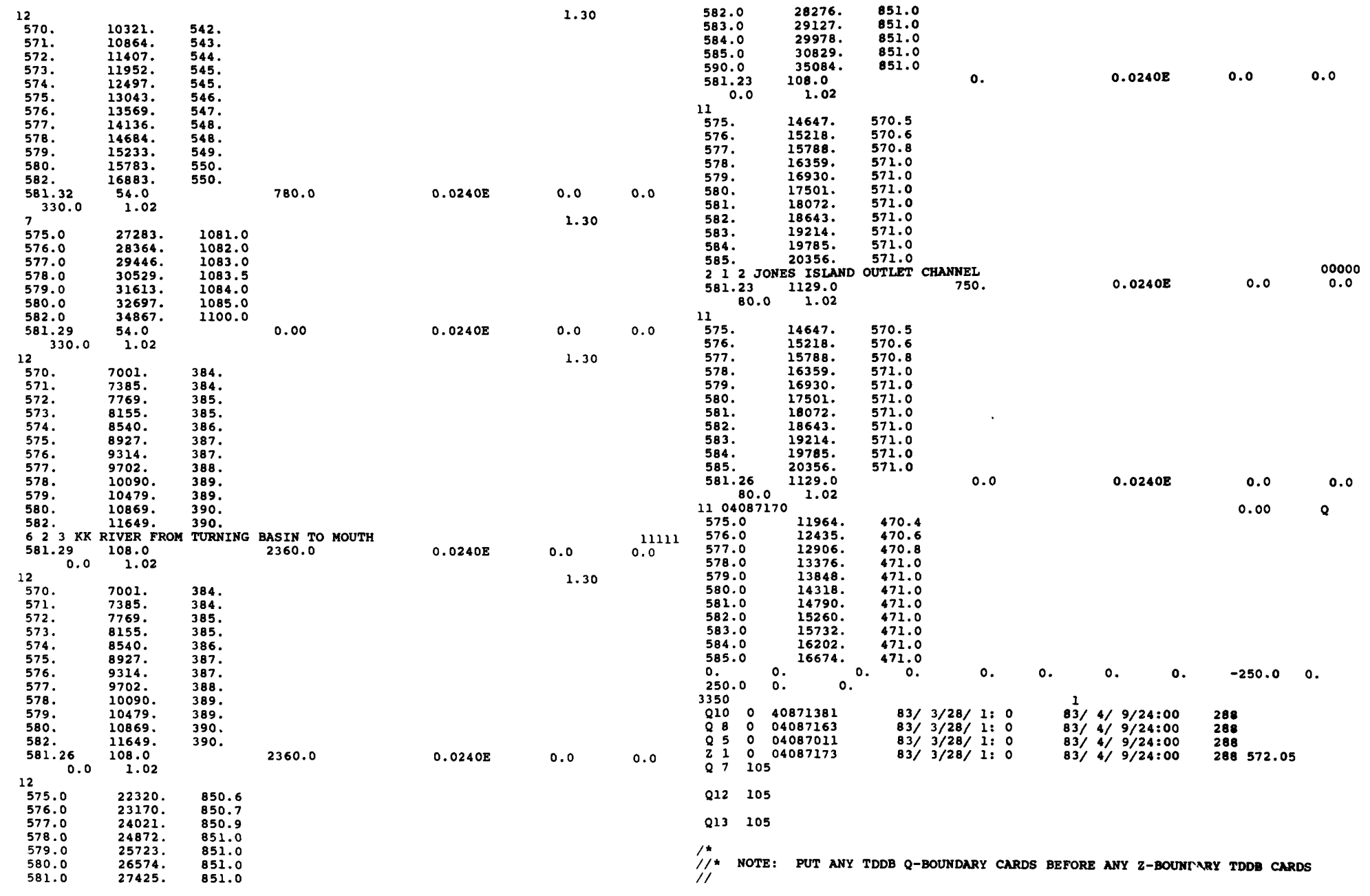


